\title{
Rural Infant Mortality in Nineteenth Century Norway ${ }^{1}$
}

\author{
Gunnar Thorvaldsen
}

$\mathrm{M}$ uch previous research on the Norwegian mortality decline has focused on specific localities, employing databases with linked microdata. One good choice is Rendalen, a parish on the Swedish border, representative of the world record low Norwegian mortality rates. The focus on the role of women, given their access to more abundant material resources towards the end of the eighteenth century, is a most interesting explanation for the declining level of infant mortality. ${ }^{2}$ Another well-researched locality is the fjord-parish Etne, south of Bergen, where infant mortality was significantly higher - also an area where the role of women is highlighted. More recent studies have been done on Asker and Bærum, south of Oslo, with infant mortality levels closer to the national average.

The present article will not attempt to match these penetrating studies of wellresearched rural localities, nor William Hubbard's insights into many aspects of urban mortality. ${ }^{3}$ Rather it broadens the scope to include the whole country. My study is limited primarily to Norway's sparsely populated rural areas, where 90 percent of the population lived in 1801, a figure that was declining towards 60 percent by 1900 , when the national infant mortality rate (IMR) had fallen below ten percent. ${ }^{4}$ My basic aim is to track the development of infant mortality rates in Norway over time, and, where possible, to say something about regional differences in the proportion of children who died before they reached their first birthday. The

1 Another version of this article will also be published inStudies in Mortality Decline. Report from the Mortality Studies Group, ed. Sølvi Sögner. Centre for Advanced Study, (Oslo, 2002).

2 Sølvi Sogner, "A Case Study of Women's Role and Infant Mortality," in Women"s politics and women in politics: in honour of Ida Blom, eds. Sølvi Sogner and Gro Hagemann (Oslo, 2000), 325. Kungliga Statistiska Centralbyrån, "Årstidernas inflytelse på dödligheten," Statistisk tidskrift, 55-57 (1879), 87-121.

3 William Hubbard, "The Urban Penalty: Towns and Mortality in Nineteenth Century Norway," Continuity and Change 15:2 (2000), 331-350.

4 Statistics Norway, Historical statistics 1994, table 3.1. 
data is taken from a variety of sources: the printed official statistics available from 1855 onward, the computerized version of these statistics covering the period from 1876 to 1920 , and from statistics compiled from church records either in original or digital formats. As will become evident, I am heavily indebted to many persons and institutions that have facilitated access to the primary data. Although the picture of infant mortality is complex, I shall try to discuss a couple of alternative explanations behind the data series.

My focus on the geographical dimension may need some defense. For an historian it seems more natural to study first and foremost the dramatic decline in infant and other types of mortality over time; in some places nineteenth century infant mortality rates decreased from around one third of all births to current levels below one percent. Since a similar trend toward decline can be found in most places in our part of the world, the study of spatial differentials may seem redundant. As early as 1855 the pioneering demographer and sociologist Eilert Sundt showed that the mortality curves of different localities did not develop similarly, nor were they at the same levels. For instance, while towns usually displayed the highest mortality rates in the nineteenth century, those in rural areas often were relatively higher during the twentieth. While such spatial differentials and their relative development may be comparably slight, they can shed much light on the causes behind the general level and trends of the corresponding mortality rate. In addition, the recent news about problems with increasing mortality among small children in northwestern Russia, shows the value of historical regional studies for understanding the current situation. However, when medical personnel in locu report the problems they have finding straightforward explanations for contemporary increases in mortality, it should cause historians to be a bit humble about gleaning universal causal factors from their often scanty source material.

Perhaps because of the vagueness and complexity inherent in the discussion about causes of mortality, a number of competing hypotheses have been put forward. Given the seasonal differences in mortality cycles when comparing northern and southern Europe, the effect of climate has become a strong candidate. ${ }^{5}$ The replacement of the miasmatic paradigm with the bacteriological shifted the focus of researchers to other factors, but climate is still a basic element in mortality differentials. From the 1960s the main debate has been between researchers favoring the nutritional argument ${ }^{6}$ and those stressing the importance of the epidemic climate. A more recent twist to this debate is to combine these two viewpoints, formulating more clearly than McKeown a theory of the synergistic effect of malnutrition and

5 Kungliga Statistiska Centralbyrån, “Årstidernas inflytelse på dödligheten," Statistisk tidskrift, 55-57 (1879), 87-121.

6 Thomas McKeown, The modern rise of population (London, 1976). 
disease, in addition to putting forward a competing theory focussing on the importance of social dislocation in order to explain mortality. For the development of infant mortality rates in particular, however, it is still topical to highlight the role of nutrition, since it seems that differential infant mortality rates may be heavily correlated with the use or lack of breast-feeding in different localities. ${ }^{8}$ While the cyclical dispersion of breast-feeding was important, ${ }^{9}$ it can certainly not explain all geographic differences. The mothers' child care practices more generally and, from ca 1900 , public measures to improve the health of infants must have been important. ${ }^{10}$

Some of the vagueness inherent in determining the causes behind shifts in infant mortality levels is also mirrored in the authoritative Norwegian Health Atlas. ${ }^{11}$ Although it cannot be proven, the authors find every reason to believe that the work of the health stations was a major influence behind the relatively low infant mortality in Norway in the twentieth century. The first such station was started in Oslo in 1911, in order to "provide inexperienced mothers with guidance, encourage and reward mothers who wanted to breast-feed."

\section{The National Level}

Official infant mortality rates for Norway exist from 1836, but only for the national level. ${ }^{12}$ Figures for earlier periods must either be modelled on the basis of other available statistics, such as the age distribution in the 1801 census and the crude death rate from 1735, or be compiled from the baptismal and burial registers in the church books. The latter approach is very laborious since only a fraction of the church registers preserved from the eighteenth and nineteenth centuries have been digitized. There is also evidence of under-registration, especially of infant deaths, in the period before 1820, when standardized forms were lacking and the clergy kept their records in their own fashion. (To some extent this is compensated for in relative terms by a corresponding under-registration of births.) There were 320 parishes

7 Kari J. Pitkänen, Deprivation and disease: mortality during the great Finnish famine of the 1860s. Suomen väestötieteen yhdistyksen julkaisuja (Helsinki, 1993).

8 Anders Brändström, "De kärlekslösa mödrarna:" spädbarnsdödligheten i Sverige under 1800-talet med särskilt hänsyn till Nedertorneå. Umeå Studies in the Humanities, vol. 62 (Umeå, 1984).

9 Marilyn Yalom, A history of the breast (New York, 1997).

10 Anne Løkke, Døden i barndommen (København, 1998).

11 Asbjørn Aase, Nasjonalatlas for Norge. Helse (Hønefoss, 1996).

12 Statistics Norway, Historisk statistikk $1994=$ Historical statistics 1994 (Oslo, 1995). 
Figure 1. Norwegian infant mortality rate (partly projected) 1735-1993.

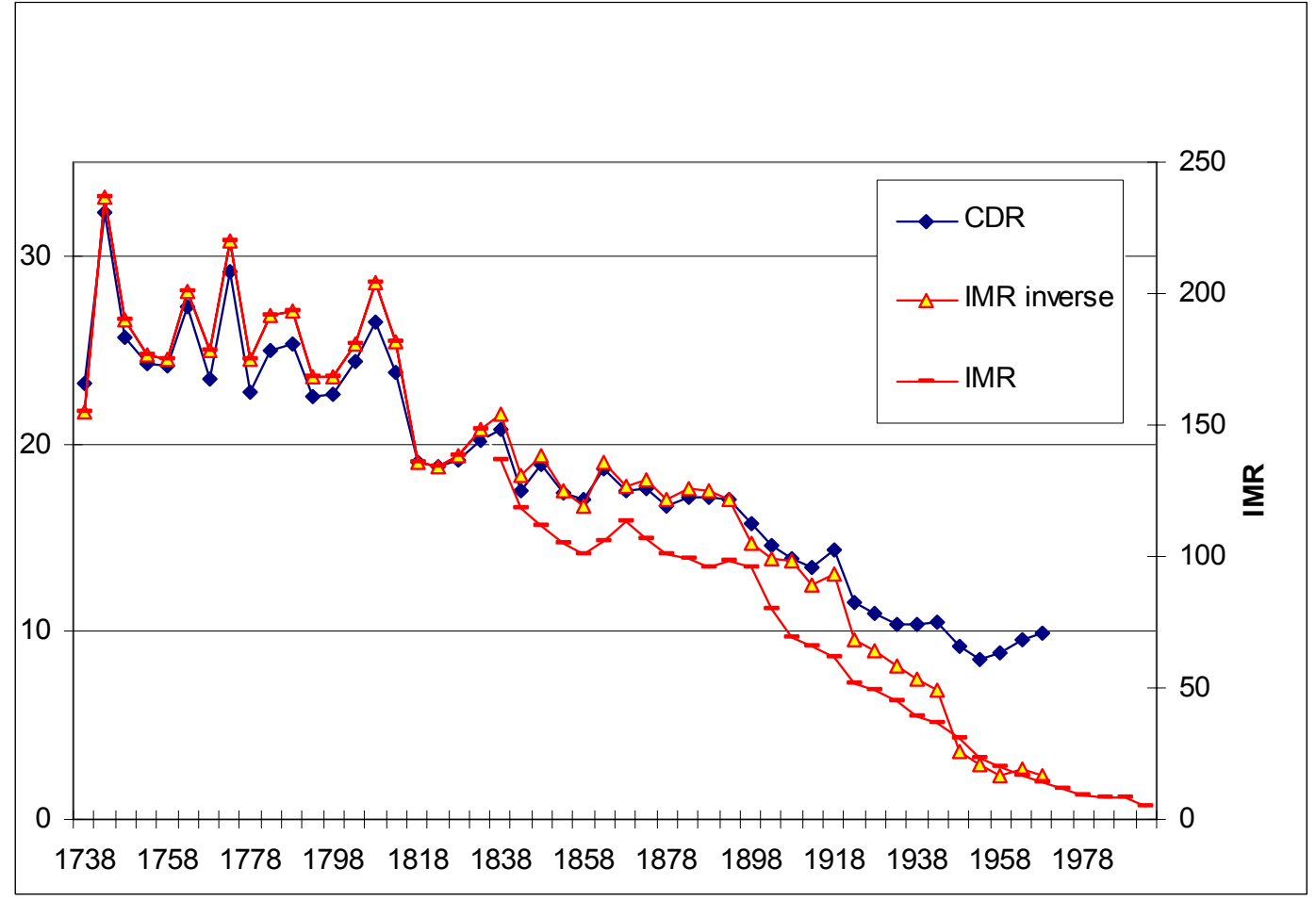

Source: McCaa (1989) and Statistics Norway, Historical Statistic (1994).

in 1801, and the lack of standardization in the sources makes manual counting quite a challenge.

Figure 1 is an attempt to graph the development of the infant mortality rate and the crude death from 1735 to 1993. Before 1836 I have used a technique for backwards projection, ${ }^{13}$ and in order to test this, crude death rate the projection was also continued after that point in time. It can then be seen how the projection tends to overestimate IMR somewhat, which may be due to the disappearance of babies as emigrants. ${ }^{14}$ This was a less important factor before 1836, and it is also possible that the real IMR curve, especially during crisis years, could deviate more from the CDR curve, on which it is modelled. However, the general decline during the first part of the nineteenth century may be close to reality, since the local studies I refer to below also suggest a national rate of about 180 dead infants per thousand born around 1800. In addition, we may be confident about the disappearance of the

13 Robert McCaa, "Populate. A Microcomputer Projection Package for Aggregative Data Applied to Norway, 1736-1970," Annales de démographie historique (1989), 288-298.

14 Prior to 1866 , emigration may be too small to support this hypothesis, although families with many children were an important part of early US emigration from Norway. 
peaks after 1812 (with the exception of some localities) and the generally declining trend, especially after 1900. The 1860s and the two world war periods were exceptions with slightly increasing infant mortality levels.

How does this compare with data from other countries? In Sweden Tabellverket (Swedish Population Statistics) started compiling detailed aggregate data on the local level, as early as $1749 .^{15}$ The Swedish IMR curve follows the Norwegian closely, although at a somewhat higher level, usually a couple of percentage points. When the Swedish series started, 1751-1755, 205.7 dead out of 1000 infants born were reported, while the projected figure for Norway is 177. Both series peaked in 1806-1810 with rates of 211.5 for Sweden and 204 for Norway. The first Norwegian empirical figure was 137 deaths per thousand for the mid-1830s compared to Sweden's 166.4. At the turn of the next century (1900) the figures were 100.5 per thousand for Sweden and 96 for Norway. Not until the Second World War did Sweden's infant mortality rate rank below Norway's (31 versus 37 deaths per thousand). These relative positions have since been maintained, with Norway now at a rate of one percent, while Sweden has declined to five deaths per thousand, reflecting the more centralized and urbanized Swedish society with easier access to medical information and services.

A comparison with several other countries undertaken around $1900^{16}$ shows that better conditions were generally provided for infants in the northern, Protestant countries than in the southern, Catholic areas. The chart from this report (Figure 2) shows how Norway was followed by Scotland, then Sweden and Denmark, and finally England during the second part of the nineteenth century. Austria, Italy and the southern German states can be found above the 25 percent line, while France had a rate only slightly above the best Protestant countries. The main exceptions from the described IMR divide through Europe are the rather inexplicably low level of Ireland and the high levels of Finland and Iceland (the latter not presented in the chart). This, as well as the high rates in Catholic countries, has been explained mainly by their relatively less frequent use of breast milk, and in the Finnish case, contagion from the east has been considered a factor. ${ }^{17}$ Among white immigrants to

15 The series 1749 to 1859 has been digitalized by the Demographic Data Base of Umea University. Cf. <http://www.ddb.umu.se/index_eng.html>. Cf. also Statistics Sweden, Befolkningsutvecklingen under 250 år. Historisk statistik för Sverige, Demografiska rapporter, vol. 1999:2 (Stockholm, 1999).

16 Axel Johannessen, Dødeligheden i Norge af børn under 1 aar (Christiania, 1902).

17 Ólöf Garðarsdóttir, Loftur Guttormsson and Guðmundur Hálfdanarson, "Ungbarnaog barnadauði á Íslandi 1771-1950. Nokkrar rannsóknarniðurstöður., Saga (2001); Ulla-Britt Lithell, Kvinnoarbete och barntillsyn i 1700- och 1800-talets Österbotten. (Uppsala, 1988). Kari J. 
Figure $2.19^{\text {th }}$ century infant mortality rates for a number of European countries.

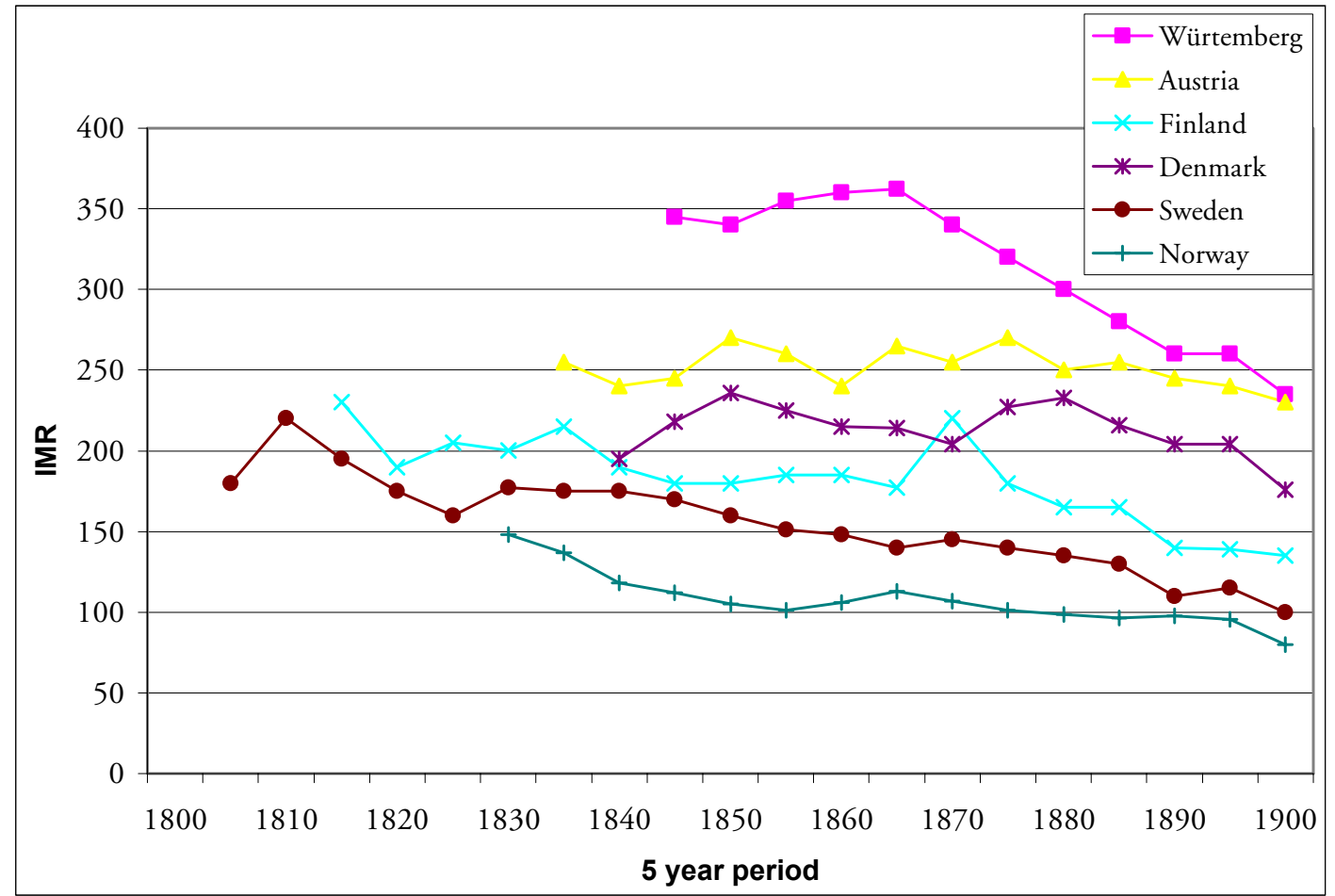

Source: Johannessen, Dødeligheden I Norge af børn under 1 aar (1903) og Løkke, Døden I Barndommen (1998).

the US, infant mortality rates were not much higher than in Norway around 1900, but probably significantly higher fifty years earlier, although early IMR figures for the US build on scanty evidence. ${ }^{18}$

The inadequate registration of vital events for most parts of the US renders detailed studies of age-specific mortality difficult, referring researchers to genealogies, retrospective census variables and church registers from selected congregations. England has better data from the 1860s making possible the mapping of the IMR on the county level. ${ }^{19}$ Throughout the nineteenth century, its variation among the regions was far from uniform, but the mean was quite constant, around 150 deaths per thousand, with a range from 70 to 250 . For Germany one study uses regional

Pitkänen, "Infant Mortality Decline in a Changing Society," Yearbook of Population Research in Finland (1983), 46-74.

18 Rasmus Sunde, "Vikjer ved fjorden - vikjer på prærien. Ein demografisk-komparativ studie med utgangspunkt i Vik i Sogn" (Dr art, Universitetet i Bergen, 2001). Michael R. Haines and Samuel H. Preston, Fatal years: child mortality in late nineteenth-century America (Princeton, N. J., 1991).

19 Robert Woods and Nicola Shelton Woods, An Atlas of Victorian Mortality (Liverpool, 1997). 
data from the last decades of the nineteenth and the first decades of the twentieth century to correlate CDR and IMR with various socio-economic and demographic background factors, the mean infant mortality declining from 250 to 70 deaths per thousand during the period. ${ }^{20}$ The regression model shows that religion, urbanisation, population density and fertility were significantly related to mortality in the direction expected, while the effects of income were inconsistent. However, there was no correlation between population growth rates or the proportion of licensed doctors and mortality rates. A residual effect from the regional variable suggested that undocumented differences in nursing practices may have been important. Over time the regional mortality differentials became smaller.

In Denmark, a recent dissertation has established relatively stable IMR regions, with towns bringing up the infant mortality rates in their vicinity. Copenhagen pioneered the decline in IMR around 1900, although it had the highest rates earlier. ${ }^{21}$ Another study dealing with the decades around 1800 found higher rates, as well as more local and regional variations over time. ${ }^{22}$ Most notably in Sweden, the availability of series of local data from 1749 makes possible detailed study of the development of infant mortality for small areas. One group of experts has devised an ingenious special method to bring together similar localities in order to remedy the problem of small numbers from their tiniest geographical units. ${ }^{23}$ When studied in this way, Gustav Sundbärg's authoritative division of Sweden into three ideal demographic units (1910) turns out to be misleading because of internal diversity. Even in the low mortality province of Jämtland on the border with Norway, some parishes displayed above average infant mortality. The discovery of contiguous high infant mortality parishes along the Swedish-Finnish border, where both sides were dominated by ethnic Finns, ${ }^{24}$ points in the direction of the role of ethnicity as an interesting background factor there, as well as in multiethnic northern Norway. ${ }^{25}$

20 Michael R. Haines and Hallie J. Kintner, "The Mortality Transition in Germany, 1860-1935: Evidence by Region," Historical Methods 33:2 (2000), 83-104.

21 Anne Løkke, Døden i barndommen (København, 1998).

22 Hans Chr. Johansen and Axel Skytthe, Danish Infant Mortality, (Odense, 2000), 13.

23 Anders Brändström, Sören Edvinsson and John Rogers, "Infant mortality in Sweden. Creating Regions from Nineteenth Century Parish Data," Historical Methods 33:2 (2000), 105114.

24 Anders Brändström, "De kärlekslösa mödrarna": spädbarnsdödligheten i Sverige under 1800-talet med särskilt hänsyn till Nedertornea, Umeå Studies in the Humanities, vol. 62 (Umeå, 1984); Kari J. Pitkänen, "Infant Mortality Decline in a Changing Society," Yearbook of Population Research in Finland (1983), 46-74.

25 Gunnar Thorvaldsen, "Infant Mortality in Northern Finland, Sweden and Norway," (Paper for the Social Science History Conference, Pittsburgh, 2000), 17. 


\section{Regional and Local Time Series}

While the national series of published infant mortality rates for Norway extend back to 1836 , the first on a more local or regional level were printed for the period 18561865 (NOS C No 1, Folkemengdens bevegelse) by Tabellkontoret, a forerunner of Statistics Norway. The administrative report unit chosen was probably a compromise between a table for all parishes, which proved too labor-intensive, and collapsing the information into a short table, listing each of the seventeen provinces. ${ }^{26}$ Instead the country's 75 deaneries were chosen as the reporting level. Since IMR levels dropped significantly during the second half of the century, it is strange that the earliest regional data sets have never been exploited by researchers until recently. A possible explanation for this may be the incompatibility of the reporting level with modern tools, such as the Municipality Database, and the lack of computerized maps. These problems could, however, be overcome with OCR and cartographic software. ${ }^{27}$

The resulting distribution of infant mortality rates for the last part of the 1850s across the Norwegian deaneries is shown on the map (Map 1). ${ }^{28}$ Somewhat paradoxically, this map shows that the main explanation for the record low infant mortality rates in sea-oriented Norway can be found in the inland areas. While the national rate stayed above ten percent until the 1880s, the interior of the country is almost consistently below that threshold, and coastal deaneries often display higher figures. This is especially the case in the north where all deaneries reached the coast, and all deaneries lying north of the polar circle had rates higher than the average. The second high level area can be found along the coast and fjords of western Norway, especially in Nordfjord and around Bergen, whereas, in the Christiania area (Oslo), the high rate may have been due to urban influence. The third high level area is found in Setesdalen, a valley stretching northwards from Kristiansand. These landlocked deaneries form important exceptions from the coast-inland dichotomy, just as the coastal deaneries of the middle part of Norway consistently show below

26 Province is used for the Norwegian amt or fylke instead of county with its connotation of a much smaller area.

27 The tables were digitized with the OCR program Omnipage, and a modern municipality map was edited to show 1865 deanery boundaries derived from Harald Winge and Steinar Imsen, Norsk historisk leksikon (Oslo, 1999), using Mapinfo. Modern map coordinates from Mapinfo Corporation were chosen as a basis rather than historic municipality maps from the Norwegian Social Sciences Data Services, since the former use the same projection as Swedish and Finnish maps, making comparative regional studies across national borders more feasible.

28 The intervals and colors are the same as those used by Løkke (1998), giving a good impression of the higher proportion Norwegian parishes with IMR below 100, when compared to the Danish. 
Map 1. Infant mortality rates, 1856-1860.

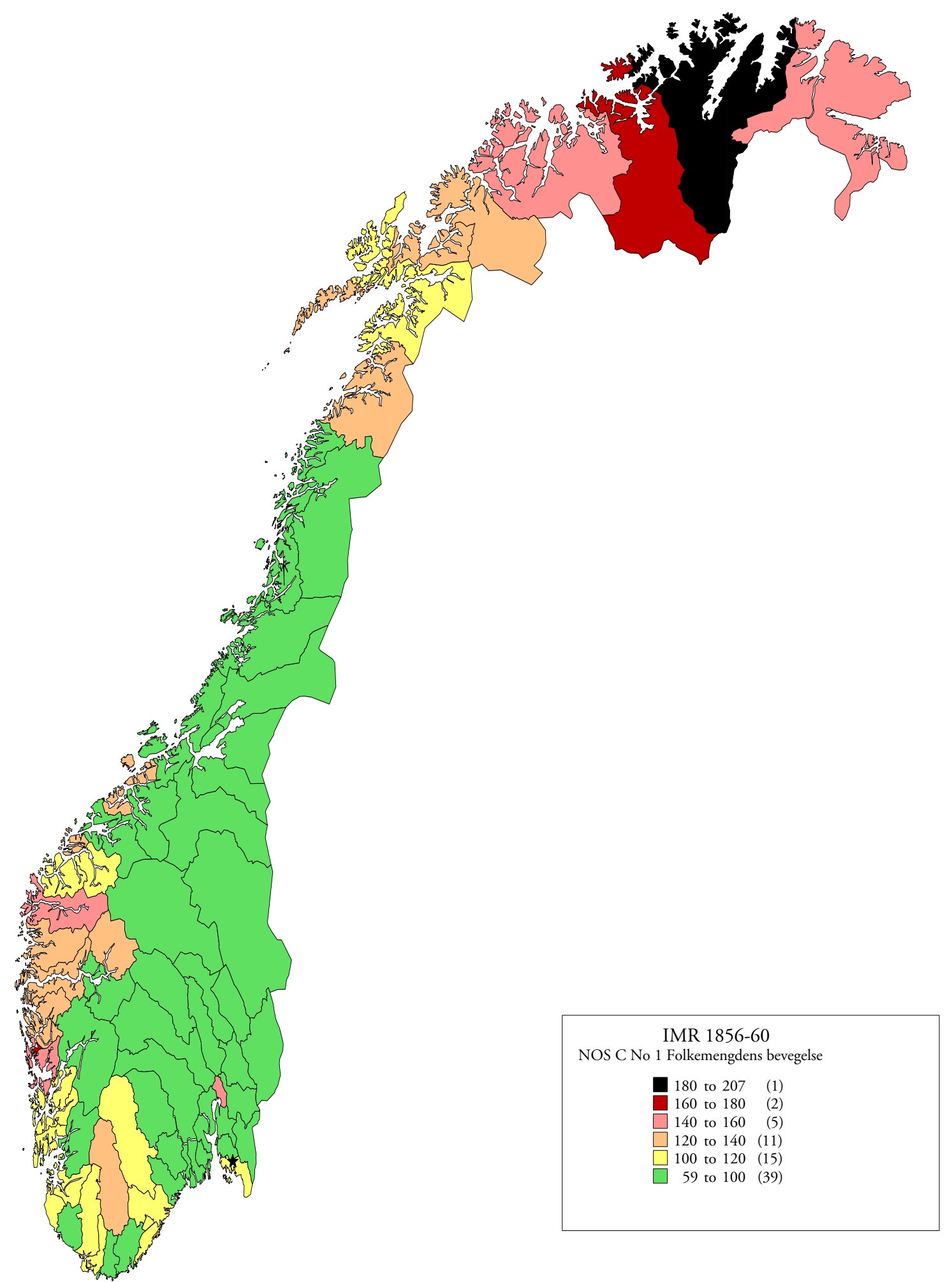

Source: Statistics Norway: Tablaux du movement de la population. I C No 1 1856-1865. 
average levels. In the southern parts of Northern Norway, we find three deaneries with suspiciously low infant mortality rates, around 60 per thousand. This result necessitated a control against the church records, which confirmed the low number. No conspicuous lacunae in the burial registers could be found, for instance the parish of Alstahaug had as low an IMR as the whole Helgeland deanery, of which it is a part. Thus, both the highest and lowest infant mortality rates of pre-industrial Norway can be found inside the same region, Northern Norway, and in deaneries bordering on the sea.

The late 1850 s was a period with relatively good harvests, a stable climate and few epidemics. In the early 1860s harder times struck, and harvest problems were reported by several administrative reports from the provinces (Amtmannsberetningene 1861-1865) due to bad weather. The epidemic climate also worsened with several waves of children's diseases, especially measles. This was followed by increased crude death rates and infant mortality rates, the latter rising from 101 to 106 deaths per thousand live births on the national level. A comparison of the maps for the two quinquenniums under scrutiny (last map not shown here), shows that the regional distribution of IMR levels had changed little. In southern Norway there was an even more pronounced inland-coastal pattern, and in the north we still see the contrast between areas north and south of the polar circle. The contrast between the western and eastern parts of the northernmost province, Finnmark, was more distinct, and in the southernmost deaneries the IMR increased markedly. On the other hand there was improvement in some of the deaneries of western Norway. A closer inspection of the deanery rates shows none below the seven percent mark, and in the southern parts of Northern Norway the level had increased above eight percent or by nearly three percentage points. The deteriorating conditions are shown by the 50 deaneries that experienced increased their infant mortality rates, while there was improvement in 23 deaneries. However, because increases as well as declines occurred in both high and low mortality areas, there was no correlation between the IMR level and its development from the late 1850s to the early 1860s. As expected, most deaneries kept their relative positions in terms of having high, medium or low infant mortality, but the changes that took place from one quinquennium to the next seem to be unrelated to the IMR level.

For the decade that followed, deanery data on burials by age also exist, but these statistics were reported for one year intervals, and in 1866 and 1867 all children below age six were grouped together. Rather than aggregating this cumbersome data set, I shall now move forward to 1876 from which time Statistics Norway reported 
quinquennial data on infant mortality for each municipality. ${ }^{29}$ Map 2 shows how the area expanded in which infant deaths per thousand fell below the 100 mark. This was not only due to declining mortality, but also to increasing geographic specificity. For instance, in the interior of Troms province two big "green" municipalities had previously been part of deaneries whose population predominantly lived along the coast. Thus the deanery and municipality maps are not readily comparable. Deaneries that contained population concentrations, often with the higher mortality found along the coast, also had thinly populated inland parishes which on the latter maps "turn green" just because they are singled out with additional borderlines. But in the western part of the country there can be little doubt that new low mortality areas emerged, even along the coast. Three types of high mortality locations remained, however. One was the valley of Setesdalen in the south, the second consisted of the northernmost province of Finnmark, including the northern parts of Troms, while the third included a number of towns, most of them lying along the coast.

Even though we have easy access to IMR figures for the following quinquenniums, for the sake of brevity we shall skip a couple of decades, when the long trend in the national rate was quite stable, ${ }^{30}$ and examine the distribution of infant deaths over the Norwegian landscape right after the turn of the century, 1900 (cf. Map 3). This is the period when public measures for the improvement of infant health were being introduced and during which Professor of Medicine Axel Johannesen published his scientific findings on the phenomenon. With the advent of the new century, the average infant mortality rate for the country started to improve rapidly, having reached 80 deaths per thousand, a decline from 96 per thousand five years earlier. The general decline in most provinces necessitates the use of a new series of ranges on the map. The old ones are better for chronological comparison and for spotting "problem" areas, but they hide much of the regional variation. The green and yellow areas, denoting below average IMR, can be seen where low infant mortality was customarily found, but old high mortality areas in the south must now be included in this category. Something has obviously happened in Setesdal, and at the same time more towns have managed to creep below the average IMR level. Only seven municipalities fell into the "high" category, above 15 percent, and they are all found in Finnmark province and neighboring Kvenangen. North and east of Troms $\varnothing$, nearly all municipalities stayed above the ten percent threshold,

29 Dead infants between one and two are also reported. From 1881 to 1920 such data are part of the Municipality Database of the Norwegian Social Sciences Data Service, cf. $<$ http://www.nsd.uib.no>.

30 IMR increased by about one percentage point to 113 during the 1860 s, and by the 1870s had declined to its previous level from the late 1850s (around 100). 
Map 2 . Infant mortality rates, 1876-1880.

M - Missing data

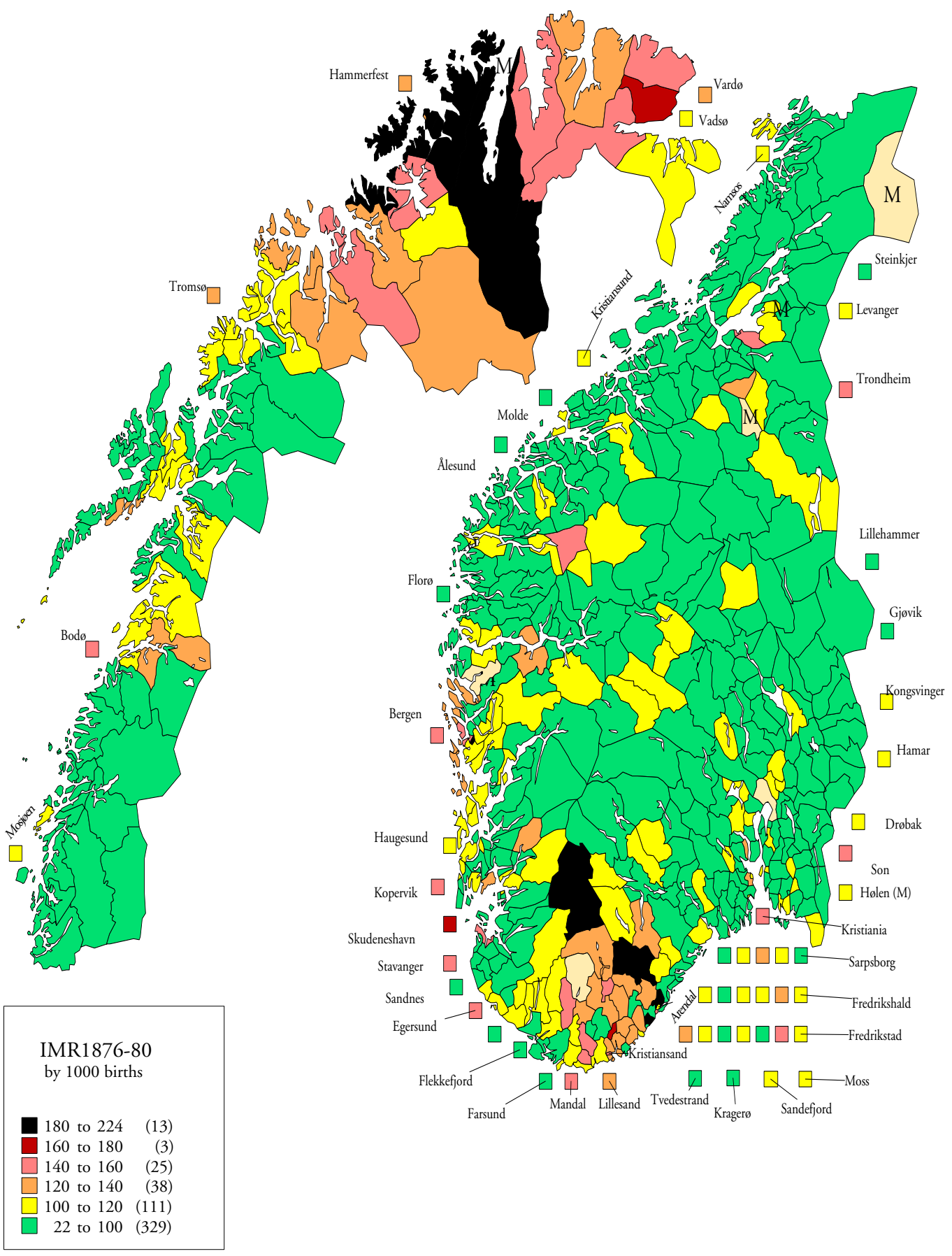

Source: Statistics Norway: Statistique du movement de la population. I C No 1 1876-18 80. 
Map 3. Infant mortality rates, 1901-1905.

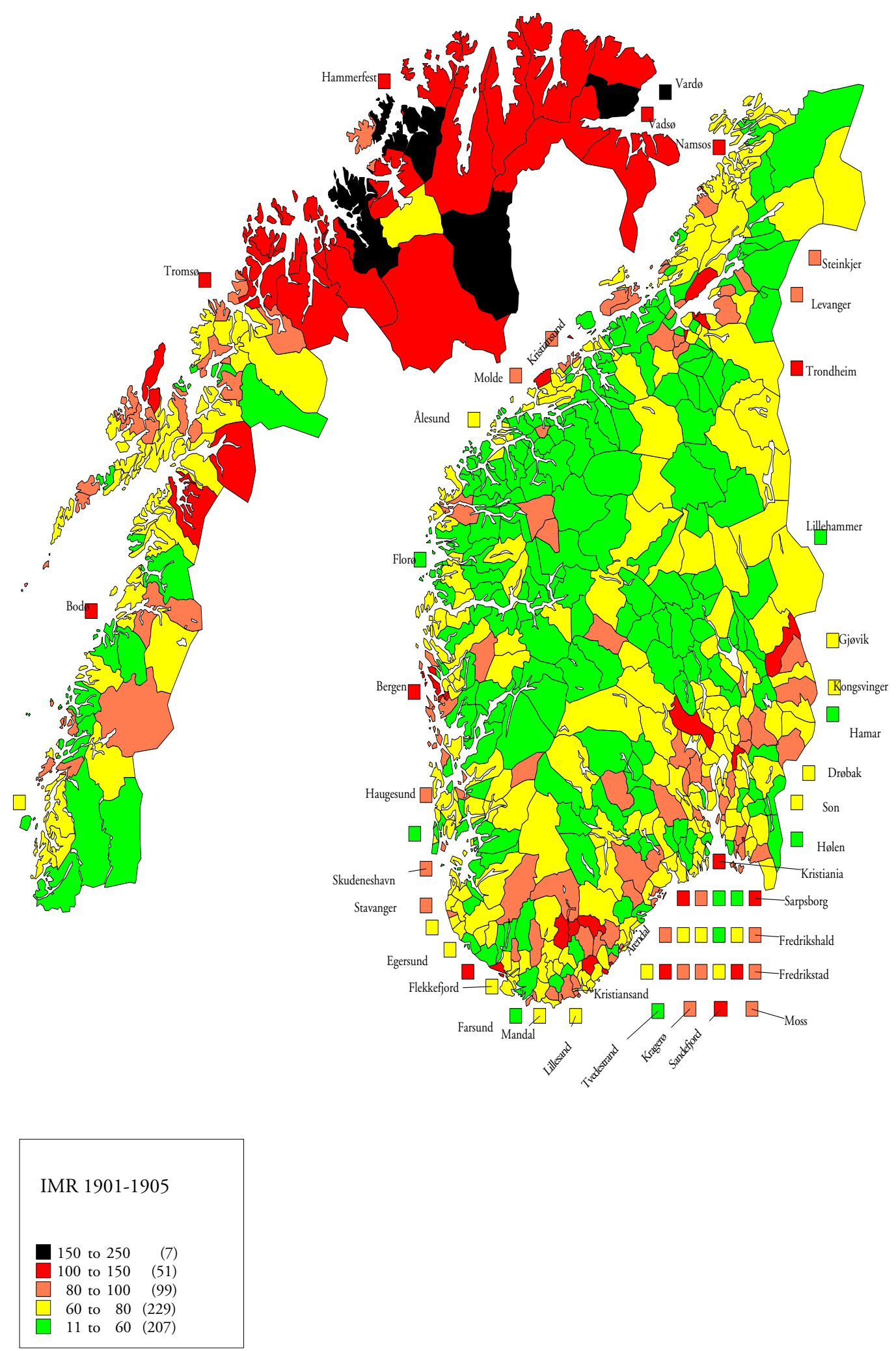

Source: Norwegian Social Sciences Data Service: The Municipality Database. 
Map 4 . Infant mortality rates, 1916-1920.

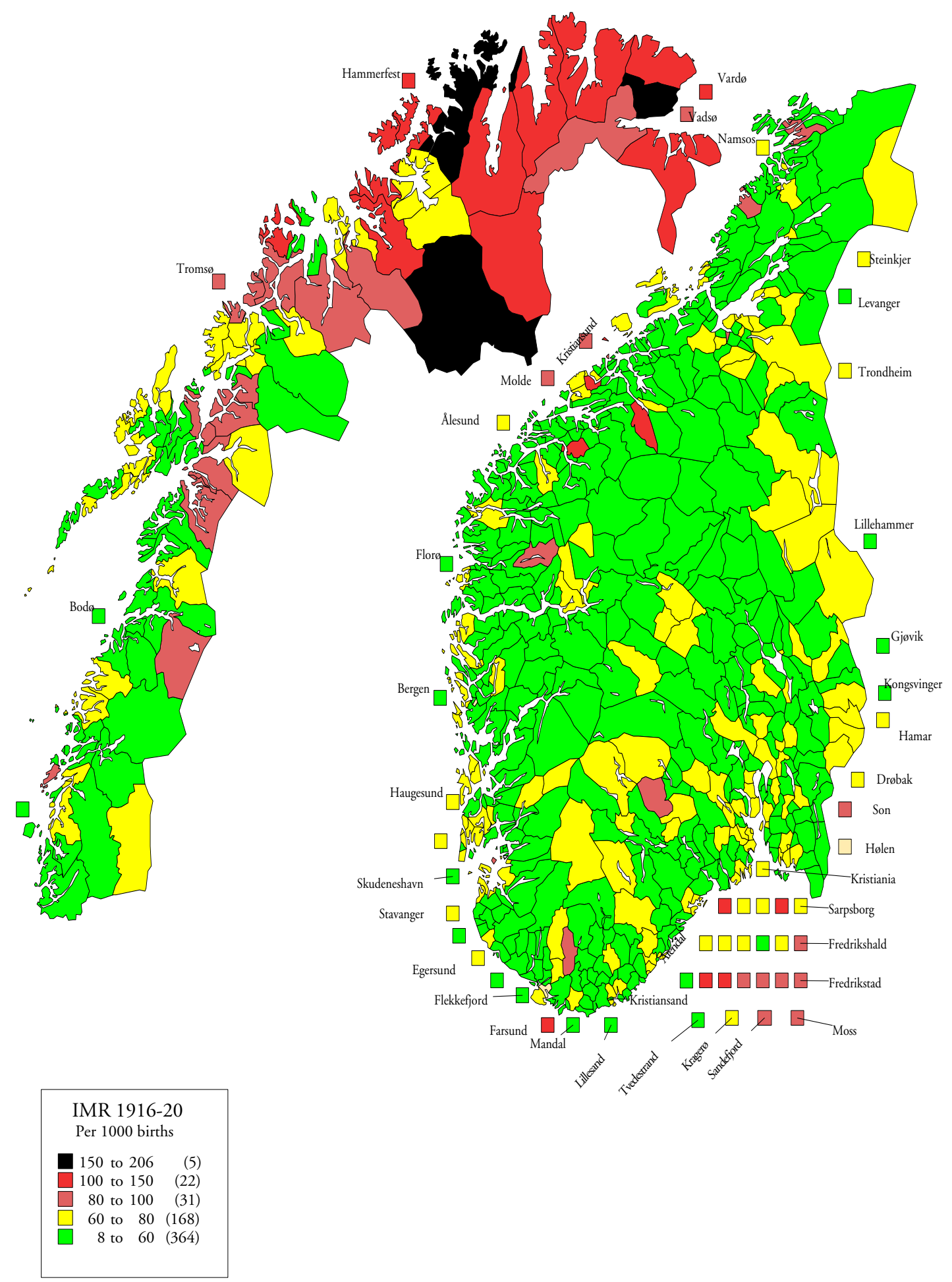

Source: Norwegian Social Sciences Data Service: The Municipality Database. 
together with a number of towns in the south. A total of 99 municipalities had infant mortality rates one or two percentage points above average, but it is not easy to see any clustering in their distribution across the map, although there is a tendency for them to be found a bit inland.

The infant mortality rate continued its decline throughout much of the twentieth century. This overview of its development on the local and regional level will be concluded by examining the period from 1916 to 1920 . This time span includes the second part of World War I, in which Norway was "the neutral ally"; the country did not participate directly, but in economic terms was part of the allied war effort with subsequent high costs of living and scarcity of some consumer items. In addition the great influenza pandemic, 1918-1919, hit Norway hard, creating the last spike in Norway's crude death rate. Since this virus epidemic mostly struck young men, however, its effect on infants was probably rather insignificant. The national average IMR for this quinquennium was down to 62 deaths per thousand, continuing its secular decline.

Our 1916 to 1920 IMR municipality map (Map 4) uses the same ranges and colors as the map showing the situation just after the turn of the century. South of the polar circle there was a marked increase in the extent of the areas with green color, which indicates areas with infant mortality below the new national average. Furthermore, a large proportion of the towns fall into the categories below or just above the average IMR. North of the polar circle there were also several municipalities where infant mortality had improved. But most places in Finnmark and the northern part of Troms province still had high infant mortality rates, and, as in the period 1901-1905, all municipalities in the category above fifteen percent were part of (an extended) Finnmark. The line graph of selected provinces in Figure 3 clearly shows how the secular decline in Finnmark's IMR was slow for a couple of decades after the towns, as a statistical category, started to rapidly improve their levels around the turn of the century. Before and during World War II the difference between Finnmark and the rest of the country became quite small, but there were still pockets of infant mortality well above average. Most notable is the predominantly Sami municipality of Kautokeino, where the IMR remained above five percent in the early 1950s. ${ }^{31}$ The district doctor found it difficult to establish the cause of death due to inadequate transportation during the long winter. By the 1980s most of the inter-provincial differences in infant mortality had disappeared, with

31 Knut Rein, "Spebarndødeligheten i Kautokeino 1946-1955," Tidsskrift for Den norske legeforening, 76 (1956), 815-816. For a study of ethnic mortality differentials in the US, see S. R. Johanson and S. H. Preston, "Tribal Demography: The Hopi and Navaho Populations as seen through the census manuscripts of the US Census of 1900," Social Science History, 3:1 (1979), 133. 
Figure 3. Infant Mortality Rates 1876-1950 for Selected Provinces and Rural/ Urban.

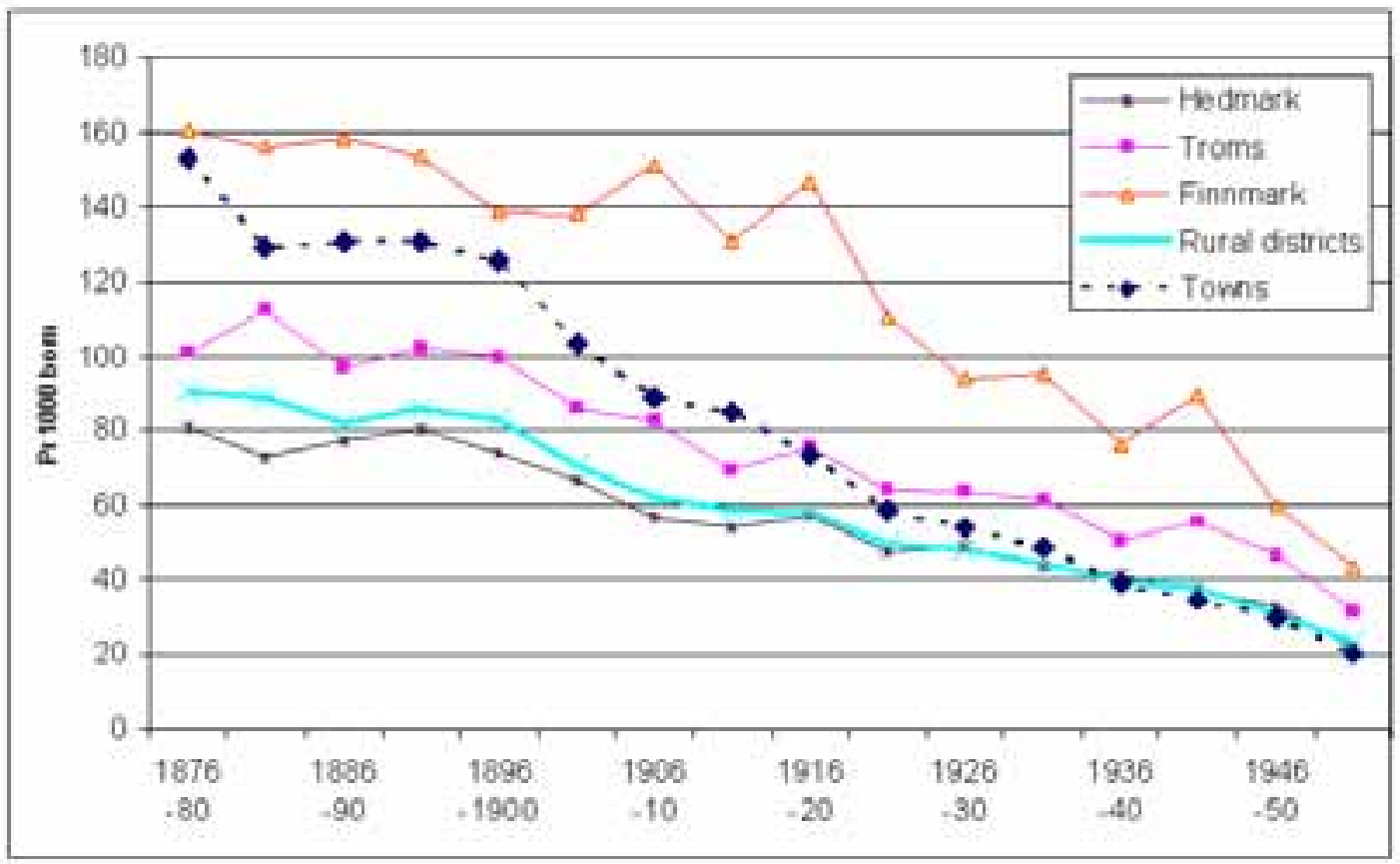

Source: Becker, Trend of mortality and causes of death in Norway 1856-1955 (1961).

Rogaland province remaining highest due to the relatively frequent instances of sudden infant deaths. ${ }^{32}$

As stated above, Norway does not have published infant mortality rates for the period before 1836, and no regional series of this kind before 1856. This is a serious lack of basic data, since both local Norwegian data and the national time series for Sweden show a substantial decline in IMR levels during the preceding decades. ${ }^{33}$ An attempt has been made to model the IMR development for each of the four dioceses back to 1736 on the basis of crude death rates, census age distributions and

32 Asbjørn Aase, Nasjonalatlas for Norge. Helse (Hønefoss, 1996), $44 \mathrm{f}$.

33 Sølvi Sogner, "A Case Study of Women's Role and Infant Mortality," in Women's politics and women in politics: in honour of Ida Blom, eds. Sølvi Sogner and Gro Hagemann (Oslo, 2000), 325; Anders Brändström, Sören Edvinsson and John Rogers, "Infant mortality in Sweden. Creating Regions from Nineteenth Century Parish Data," Historical Methods 33:2 (2000), 105114. 
other predefined conditions. ${ }^{34}$ However, as is evident, to the degree that infant mortality behaves differently from the mortality trend in general, which was probably the case during the several crisis years of the eighteenth century, IMR levels for different regions will not be truly comparable.

An obvious alternative is rather to work from the entries in the baptism and burial records of the church registers. These exist from 1623, but it is unfortunately not until the eighteenth century that they cover a substantial number of Norwegian parishes and report age of death. Before the second decade of the nineteenth century these sources had no predefined layout, so the variation in contents, style and handwriting is great. Some clergymen have provided us with neat tables of the number of dead and children born at the end of each year, increasing our confidence in the reliability of his information, while others kept their records in the form of a diary, noting weddings, burials and baptisms chronologically. It has been estimated that the proportion of missing cases may be as high as one third, but around the end of the eighteenth century, a more common estimate is eight or ten percent. ${ }^{35}$ There may have been local variation in under-registration, or perhaps infant burials were not considered as important entries as other vital events. ${ }^{36}$ As mentioned above, missing deaths may to some extent compensate for the missing baptismal entries.

Since the quality of some church registers prior to 1812 is inadequate, we shall never know the exact infant mortality rate for the period before and during the last Norwegian mortality crisis at the time of the Napoleonic Wars. But it is still possible to base reasonable estimates on local studies. Several such investigations have already been conducted and are primarily of two types. Classic family reconstitution has been most usual with its rich possibilities to combine several data types for source critical purposes. Especially when information from many sources can be utilized through a database system, ${ }^{37}$ the estimated IMR level, is in all

34 Gunnar Thorvaldsen, "Infant mortality in Norway 1735-1900. An overview," (Conference paper, Umeå, 1999).

35 Gunnar Thorvaldsen, Håndbok i registrering og bruk av historiske persondata (Oslo, 1996).

36 Ragnhild Høgset, "Begravelsesskikker og trosforestillinger i det gamle bondesamfunnet. - en feilkilde når en bruker de gamle kirkebøkene til å studere dødelighet?” Historisk tidsskrift, 68:2 (1990).

37 Ståle Dyrvik, "Spedbarndøden i Etne prestegjeld 1716-1900," in Festskrift til Historisk institutts 40-års jubileum 1997, eds. Edgar Hovland, Ståle Dyrvik and Geir Atle Ersland, (Bergen, 1997), 131-150. Sølvi Sogner and Gunnar Thorvaldsen, "Differential Infant Mortality in Rural Norway: A Comparison of a High and a Low Mortality Region," (Social Science History Association Conference, Fort Worth 1999), 26. 
probability, correct for the local area in question. Even though migrants may be under-represented or some burial entries are missing, the IMR levels reported in most reconstitution studies should be comparable for different parishes and not much under the "true" number. The most recent overview of such studies can be found in a monograph by Margunn Skjei Knudtsen. ${ }^{38}$

The other type of study has concentrated on several demographic phenomena, including mortality, analyzed on the basis of information about the population of 45 randomly chosen parishes in the 1801 census. $^{39}$ In addition this project used record linkage techniques to include data from the church registers for two to five years around 1801, combining the information at the individual level. Because record linkage usually skews the resulting sample of linked persons towards nonmigrants and the more wealthy, this may have underestimated mortality among the propertyless, but it must still be safe to say that the farmers did not experience lower mortality than the cotters in early nineteenth century Norway. While Engelsen's primary aim was to study social mortality differentials, he also presented results on infant mortality in the period from 1802 to 1803 for combined groups of parishes. Unfortunately the results are not comparable with other IMR rates, since he did not use the number of births as the denominator, but rather the number of children below age one in the 1801 census. Because infant mortality naturally affects the number of surviving infants counted in any census, both the numerator and the denominator in his calculations have been affected. Not only does this render his figures incompatible with other studies; the method also means the differences reported between parishes and regions in his study are unreliable. By using the number of births in the parishes as reported by Haavet, however, it has been possible to recalculate Engelsen's figures into ordinary IMR estimates. ${ }^{40}$

38 Margunn Skjei Knudtsen, Fra frelse til helse: spedbarnsdødelighet og omsorgssyn i Norge ca 1700-1830 med sarlig vekt på forholdene i Vår Frue sokn, Trondheim (Trondheim, 1997), 83.

39 East Norway parishes: Borge, Onsøe, Aas, Sørum, Ullensager, Tryssild, Reendahlen, Aal, Sigdal, Eger, Lier, Hurum, Bolloug, Ramnæs, Sem, Thiølling, Hitterdal, Vinie; South Norway parishes: Gierrestad, Sønneløv (part of Øster Risøer parish), Walle, Mandal; West Norway parishes: Lund, Egersund, Wigedahl, Quindherret, Fanøe, Lindaas, Leganger, Kind, Selløe, Vandelven, Stranden, Sundal; Middle Norway parishes: Ørkedal, Meldal, Hitteren, Frosten, Inderøe; North Norway parishes: Brønøe, Lødingen, Ofoten, Quædfjord, Carlsøe, Loppen.

40 Engelsen reports neither the number of dead infants in the parishes, nor the number of infants according to the 1801 census, presumably because a two year span is too short to report infant mortality rates on the parish level. I had to reconstruct his denominators from the 1801 census database in order to calculate IMR for the regional groups of parishes. 
Table 1: Infant mortality rates for regional groups of parishes, 1802-1803, using the number of infants born or the number of infants in the 1801 census.

\begin{tabular}{lccccc}
\hline Parishes & $\begin{array}{c}\text { Baptized } \\
\mathbf{1 8 0 2}\end{array}$ & $\begin{array}{c}\text { Baptized } \\
\mathbf{1 8 0 3}\end{array}$ & $\begin{array}{c}\text { Dead }<\mathbf{1} \\
\mathbf{1 8 0 2 - 1 8 0 3}\end{array}$ & Regional IMR & Engelsen \\
\hline East & 1403 & 1629 & 517 & 170.6 & 198 \\
South & 260 & 280 & 100 & 185.1 & 196 \\
West & 592 & 590 & 299 & 253.4 & 204 \\
Middle & 527 & 528 & 99 & 94.0 & 105 \\
North & 308 & 313 & 125 & 201.0 & 202 \\
\hline All & 3090 & 3340 & 1141 & 180.9 & 177.4 \\
\hline
\end{tabular}

Source: Rolf Engelsen, Sosiale skilnader $i$ mortalitet på landsbygda i Norge $i$ åra 1802 og 1803. Elisabeth Haavet, Avvik eller uhell? Ugifte foreldre omkring 1800. Hovedoppgaver, Bergen, 1982.

Table 1 shows considerable differences in infant mortality between the five regions into which the 45 parishes were grouped. In the western part of the country about one fourth of the infants died, while the southern and eastern parishes had IMR levels somewhat below 20 percent. The IMR for central Norway of less than ten percent is suspiciously low, but before dismissing it on a source critical basis, it should be remembered that this was also a region with very low proportions of dead infants in the 1850s, at which time more trust can be placed in the primary material. As might be expected, the IMR figure reported for the parishes in northern Norway was higher than the average, but still significantly lower than the figure for the western part of the country. The years chosen by Engelsen may also have been special. In addition, considering the small number of parishes he has in a couple of regions, peripheral areas can affect the IMR decisively. For instance, in the northern parish of Ofoten, the IMR for 1802-1803 is close to Engelsen's average figure for his northern parishes, but the IMR the whole period 1799 to 1803 is significantly lower, only 122.2 deaths per thousand.

Ideally, IMR figures should be computed for as many parishes as possible in order to check the regional figures above and provide more detailed information on the local level. Moreover, this exercise should be done for a period as close to the 1801 census as possible, in order that its background variables may be used in multivariate analysis. This sizable task demands more time and resources than are presently available, but it is still possible to accumulate the information that is most readily at hand. In addition to results from the family reconstitution studies, I have exploited the microdata that have been digitized from the church registers for the period under examination and have also done some manual counting from the microfilmed versions of the original sources. In addition, I am indebted to colleagues who have provided information from private databases. While information about individual parishes from different sources may not be completely comparable, 
it still provides a basis for evaluating the regional figures. In this way infant mortality rates around 1800 for a total of 56 parishes can be reported. ${ }^{41}$

These results are shown in Map 5. As might have been expected, the picture is rather heterogeneous, with church books for neighboring parishes reporting IMR figures at the opposite ends of the scale. These differences may have been caused by the under-reporting of infant deaths, local epidemics of children's diseases hitting at random just before or after the period investigated, and the general problem of small numbers in single parishes. The number of rural parishes showing the highest infant mortality in the west and the lack of such parishes in the eastern part of the country, however, lend additional support to the differences found between these two regions when Engelsen's numbers are recalculated. In the other regions too few parishes have yet been studied to draw any real conclusions, but I would like to point out the low-level parishes in the middle of the country and the heterogeneous, in-between results in the north. The results for individual parishes are given in Appendix 3.

While Engelsen's recalculated figures produce a national IMR of 177.4 pro mille, my own result is 180.9, which is quite close to the estimate of 190 made previously. ${ }^{42}$ Since the figure calculated for 1801-1805 with the projection technique described above was also 181 , we should be able to say rather confidently that the infant mortality rate of Norway at the start of the nineteenth century was close to 18 percent. The Swedish figure for this quinquennium is 186.1 per thousand with females at 173.3 and males at 198.3; a similar sex difference could probably be found from the Norwegian individual level data. Between 1749 and 1815 the Swedish five-year IMR varied between 186 to 222 per thousand. ${ }^{43}$ If the assumption is made that the relative variation in IMR in the two countries was proportional to the variation in their respective crude death rates, it may be estimated that the Norwegian IMR varied between 172 and 196 deaths per thousand during the period from 1749 to $1815 .{ }^{44}$ (By plotting the IMR and CDR

41 Six of these were also part of Engelsen's sample of 45 parishes. I am grateful for data from Arnfinn Kielland, Solfrid Fagertun, a number of theses, the Province Archive in Sogn and Fjordane, and the Digital Archive. Cf. the table in appendix 3. I am especially grateful to Eli Fure for providing both data for Asker/Bærum parish and for useful comments on a draft version of this article.

42 Ståle Dyrvik, "Poteta, dødsrata og demografien," Historisk tidsskrift, 57:3 (1978), 269279.

43 Statistics Sweden, Befolkningsutvecklingen under 250 år. Historisk statistik för Sverige, Demografiska rapporter, vol. 1999:2 (Stockholm, 1999).

44 CDR varied for Sweden between 24.38 and 32.97, and for Norway from 22.5 to $29.1 \%$. 
Map 5. Infant mortality rates around 1800 for 56 out of 330 parishes.

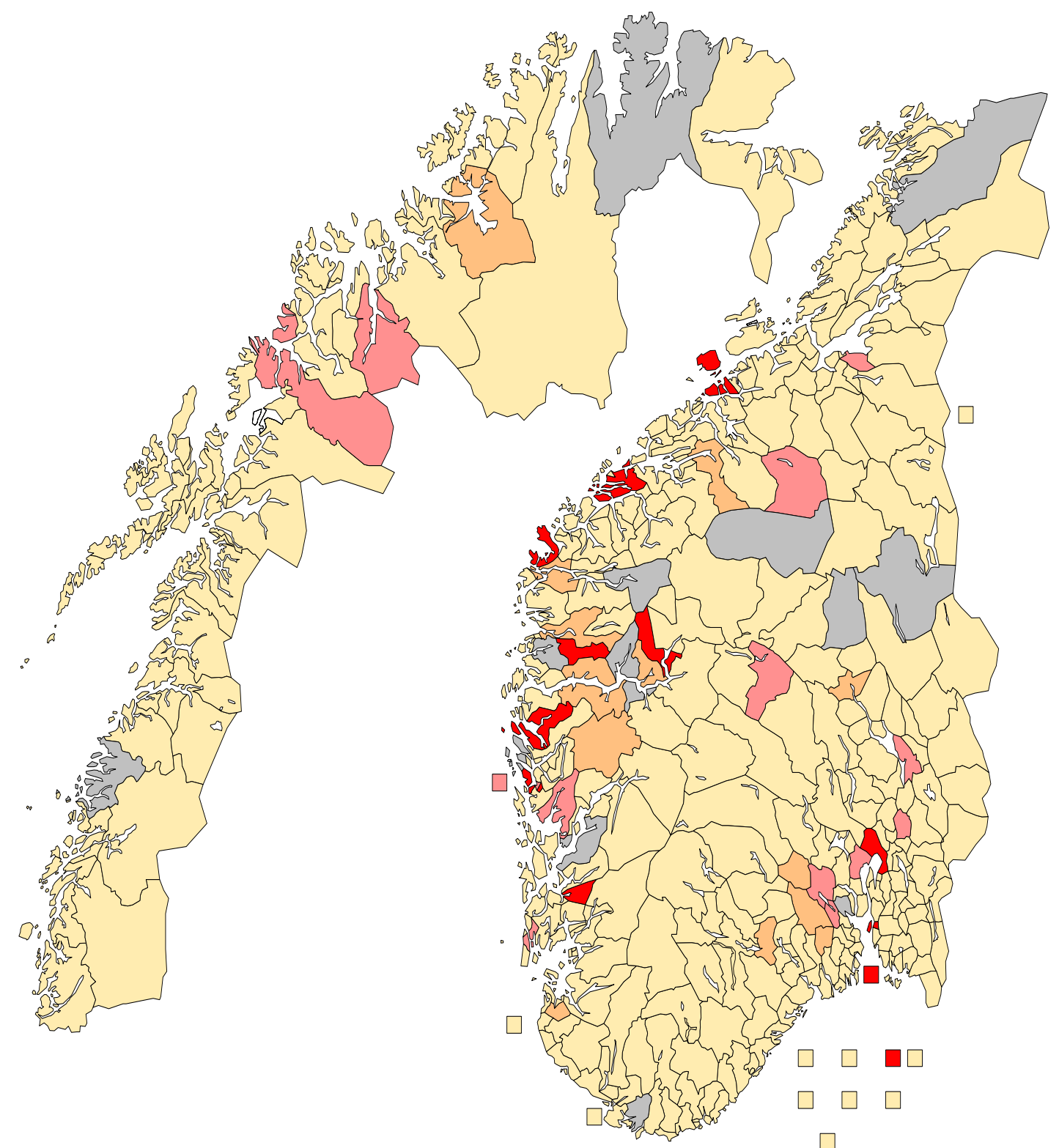

Parish level IMR ca 1801

218 to $264 \quad(12)$

$\square 188$ to $218 \quad$ (13)

$\square$
$\square$
$\square$

Source: Appendix 3. 
for Sweden in the same diagram, this assumption can be shown to be true except during the crises in the 1770s and around 1810, when the CDR increased relatively more than the IMR.) The projected Norwegian IMR varied between 168 and 220 per thousand, which is closer to the variation in Sweden. Until the church registers for more parishes have been studied for a longer period, we must be content to suppose that the quinquennial infant mortality rate probably stayed close to, or above, 17 percent from 1750 to 1815 and did not peak at much more than 20 percent. The annual or local IMR may, of course, have been lower or higher.

In summary, the infant mortality numbers above confirm the hypothesis that Norway recorded relatively low national infant mortality rates for much of the last two or three centuries. They also indicate a pattern of regional differentials, with the coastal areas reporting higher levels than the interior. For the first six or seven decades of the nineteenth century, the high coastal levels could be found especially in the western parishes north and south of Bergen. From the 1870s, however, the IMR declined in those areas, and a little later the high rates in Setesdalen disappeared, leaving the parishes north and east of Tromsø as Norway's high infant mortality area. The southern part of Northern Norway, on the other hand, consistently reported very low infant mortality rates. Until the first couple of decades of the twentieth century, many towns reported higher IMRs than the rural areas. Both "urban" and "coastal" may be seen as proxies for "densely populated," but from World War I there was a tendency for inland areas, rather than the coast, to report the highest infant mortality.

\section{Discussion}

We are fortunate to have source material enabling us to map the development of regional and even local levels of infant mortality in Norway from the second half of the nineteenth century. With much effort it is also possible to assemble data from the last part of the previous century, as I have done for the time around 1800 . However, as stated previously, it is much more difficult to explain the regional IMR differences and their development over time. Even doctors present in Finnmark in the 1950s or in northern Russia today cannot find straightforward reasons for the above normal infant mortality figures. Even so, I shall attempt a discussion of possible background factors more with the intent to stimulate future data collection and research than to present an overall standard explanation.

First, there is synergy between food supply and infections, which has been the basis of so much controversy in the debates about historical mortality. The question of nursing is postponed here to concentrate on a discussion of the possibility that infant mortality was high because people did not have the resources necessary to 
feed their families. The background is provided by the simultaneous introduction of the potato and the decline in mortality with the disappearance of crisis spikes. Even in a society where breast-feeding was usual, the nutritional conditions of the parents could be important for infants. But there is much counter-evidence. As shown in the maps, nineteenth century infant mortality was higher in most coastal areas where access to fish was better than in the low mortality inland areas mostly dependent on agricultural food production. Researchers have also found few signs that IMR differences were related to the social position of the children's families, except where the reduced levels among the lower social classes were extreme. ${ }^{45}$ When the IMR fluctuated less than the CDR in Sweden during the crises of the 1770 s and around 1810, this provides further evidence that the food supply was not the key factor behind infant mortality. Still, nutrition may have played a certain role for infants during the severe deprivation crises prior to 1815 and may have also had some effect in the growing urban centers later on. However, it is not likely to have had much importance as an explanatory factor for an IMR level of 18 percent around 1800 or 10 percent around 1900.

Thus it becomes more interesting to juxtapose the infection factor against different standards of child care, especially different ways of nursing children. Studies from the other Nordic countries have shown very convincingly how the practice or lack of breast-feeding may have had long lasting effects on IMR levels and how changes could be dramatic. In the Haparanda area in northern Sweden infant mortality declined from levels around one third of those born to levels below one fifth in connection with the midwife's breast-feeding campaign in the 1850s. The causeeffect relationship has been demonstrated convincingly in a number of ways. ${ }^{46}$ Simultaneously, in northern Finland in Ylitorneå parish an ardent campaign by the vicar in favor of better child care, including nursing, brought the IMR down by similar proportions. ${ }^{47}$ For Denmark a recent doctoral dissertation has shown the relationship between nursing practices and infant mortality figures on the parish level for many regions during the second half of the nineteenth century. ${ }^{48}$ In Iceland

45 Eli Fure, "Spedbarndødelighet og sosiale forskjeller i Asker og Bærum 1814-1878. En metode for studier på individnivå," Heimen 37:4 (2000), 293-304; Rolf Engelsen, "Mortalitetsdebatten og sosiale skilnader i mortalittet," Historisk tidsskrift 62:2 (1983), 161-202.

46 Anders Brändström, "De kärlekslösa mödrarna:" Spädbarnsdödligheten i Sverige under 1800-talet med särskilt hänsyn till Nedertornea. Umeå Studies in the Humanities, vol. 62 (Umeå, 1984).

47 Kari J. Pitkänen, "Infant Mortality Decline in a Changing Society," Yearbook of Population Research in Finland (1983), 46-74.

48 Anne Løkke, Døden i barndommen (København, 1998). 
the national IMR, between 25 and 30 percent prior to 1870 , was consistently related to feeding practices that did not include using breast milk. ${ }^{49}$

Seen against this background, the propensity for mothers in some areas or belonging to specific ethnic groups not to breast-feed during certain epochs has been called one of the biggest mysteries of historical demography. On the face of it, breast-feeding may seem to be the obvious one-and-only answer to all questions about infant nutrition. On closer examination, however, it turns out that the author of the standard popularized Norwegian reference book to promote breast-feeding has been able to fill almost 300 pages with detailed advice to mothers who want to breast-feed. The book was first published out of frustration, because so few women were able to give their own milk to their infants, even though they really wanted to. The need for guidance through the maze of complications is evidenced by the successful printing of four editions since $1970 .^{50}$ The book lists common myths about breast-feeding and why it has been believed to be more complicated than artificial nourishment: it ties down the mother; it creates a mess; the mother becomes listless and feels that special food, exercises or other precautions are necessary; the shape of the female body becomes distorted; breast-feeding is fattening; or breast-milk is too thin. The crucial factor in all this may be the self-confidence the mother needs to trust her own milk supply. This self-confidence will naturally be affected by the prevalent attitudes in her social environment and by whether she is given the opportunity and resources to spend enough time with her baby.

Cycles in the use of mother's milk are well-known from the twentieth century. Local studies from Norway indicate that in the first decades of the twentieth century more than 90 percent of the women breast-fed, a proportion that had declined to 20 percent by 1960 , before breast-feeding once again became nearly universal. ${ }^{51} \mathrm{~A}$ recent study gives ample evidence of similar cycles in earlier centuries. The erotization of the breast during the Renaissance has been linked to a decline in breastfeeding by many mothers, especially those who could afford to employ wet nurses. By the beginning of the eighteenth century, the "high-culture ideal was still that of the 'unused' breast." More than half of the British women did not breast-feed their own children, and from Paris about half of the children were sent to wet nurses in the countryside by the middle of that century. By 1800, however, breast-feeding

49 Ólöf Garðarsdóttir, Loftur Guttormsson and Guðmundur Hálfdanarson, "Ungbarnaog barnadauði á Íslandi 1771-1950. Nokkrar rannsóknarniðurstöður,” Saga, (2001).

50 Elisabeth Helsing, Boken om amming, 4 ed. (Oslo, 1995).

51 Ida Blom, "Ammerutiner - et stridsspørsmål mellom leger og mødre," in Klokskap og kyndighet: Kari Martinsens innflytelse på norsk og dansk sykepleie, eds. Marit Kirkevold, Finn Nortvedt and Herdis Alvsvåg (Oslo, 1993), 114-124; K. Liestøl, M. Rosenberg and L. Walløe, "Breastfeeding practices in Norway 1860-1984," Journal of Biosocial Science (1988). 
had been reintroduced on a large scale in both France and Britain. During the French Revolution the duty of loving mothers to breast-feed was contrasted with the tainted milk given to aristocrat children of the Ancien regime by wet nurses. Yalom gives a vivid description of commissioners drinking water splashing from the breasts of a goddess statue on the Place de la Bastille in 1793, urging the astonished onlookers to become breast-feeders. Both in France and Germany the ideal of the breast-feeding mother was portrayed in sentimental paintings and poems. ${ }^{52}$

A plethora of printed information in favor of the practice was connected with the late eighteenth century nursing campaigns in many places. The first document arguing the benefits of breast-feeding may be a doctoral dissertation presented in 1729 and printed in London in $1748 .{ }^{53}$ Such information was made more available through the publication of "An Essay upon Nursing and the Management of Children, from their Birth to Three Years of Age." This author thought that "this Business has been too long fatally left to the Management of Women" and strongly warned against giving infants cow's milk or other surrogates. The main message was that "... no Child should ever be crammed with any unnatural Mixture, 'till the Provision of Nature was ready for it; nor afterwards fed with any ungenial alien Diet whatever, the first three Months,". Cadogan's essay must have circulated widely, as it was printed eight times; a Swedish edition was printed in Stockholm in 1784. ${ }^{55}$

As early as 1755 the Collegium Medicum had the Royal Printing Office publish a 16 page brochure in Swedish entitled "On the Health and Care of Infants," strongly advocating the practice of breast-feeding. The authorities especially addressed the undesirable nursing practices in northern Finland, pinpointing "the un-Christian habit in several places in the provinces of Sweden, especially in Osthrobothnia among common people ... that the mothers, even if this is not caused by any inability, deny their infants the correct and natural nourishment of mother's milk, only because it is convenient due to their work and activities outdoors,..." The brochure then goes on to describe the practice of using cow's milk in a horn hung over the child's cradle. I have, however, found no similar information printed in

52 Marilyn Yalom, A history of the breast (New York, 1997), 105 and 117.

53 Richard Conyers, De Morbis Infantum, Printed 1748 (London, 1729). Together with many other classic works on neonatology, this text was available on the Internet at http://www.neonatology.org/classics/.

54 William Cadogan, An Essay upon Nursing and the Management of Children, from their Birth to Three Years of Age. By a Physician (London, 1749).

55 According to the digitized Swedish National Library system, Libris. 
Finnish until the Finnish State Medical Board in 1844 printed an 11-page pamphlet urging the benefits of breast-feeding. ${ }^{56}$

In the meantime literature on child care was also published in Denmark-Norway, but somewhat later than in Sweden. Breast-feeding was recommended in a couple of medical books and a number of articles published in the $1770 \mathrm{~s}$ and $1780 \mathrm{~s}^{57}$ The literature also warned against the dangers involved in taking new-born children to church for baptism during the winter. After a pause during the first decades of the nineteenth century, a new wave of literature about infant care appeared in the $1840 s,{ }^{58}$ for instance, a Danish textbook for midwives propagating rules about breast-feeding that are in accordance with late twentieth century advice. ${ }^{59}$ It has been established that information about adequate child care was available, but the question is still how widely it was circulated throughout the Nordic countries. It is generally assumed that the eighteenth century was the time when people started to read not only for entertainment or for religious purposes, but also in order to find useful information. At least in Sweden, many children had learned to read by that era, as can be seen from the dean's inspection in the parish of Råneå in Norrbotten in 1720. Around 1850 a significant part of the Swedish and Finnish population could read, but most other European countries were less literate. ${ }^{60}$ Thus, in most of Scandinavia, lack of access to information among the general public was in itself not the crucial factor for medical authorities wanting to reform nursing habits. More decisive was the resistance to reforming age-old feeding practices that were ingrained in the local culture, especially if the reformers were conceived as representing authorities whose general aim it was to get rid of "non-national" ethnic minority cultures. One author has singled out food habits as the last factor in an ethnic group's special culture to disappear in the acculturation process after

56 Oiva Turpeinen, "Infant mortality in Finland 1749-1865," Scandinavian Economic History Review, 27: 1 (1979), 1-21; Collegium Medicum, "Om Späda Barnens Ans och Hälsa," ed., G William Kammecker (Stockholm, 1755), 16.

57 Margunn Skjei Knudtsen, Fra frelse til helse: spedbarnsdodelighet og omsorgssyn i Norge ca 1700-1830 med sarlig vekt på forholdene i Vår Frue sokn, Trondheim (Trondheim, 1997).

58 Gerda Bonderup, "Døden i barndommen. Melding av Anne Løkkes bok," Historie (1999), 136.

59 C. E. Levy, Udtog af fodselsvidenskaben som larebog for jordmødre (København, 1843).

60 Robert Darnton, "History of Reading," in New Perspectives on Historical Writing, ed. Peter Burke (University Park, Pennsylvania, 1991), 140-167; Egil Johansson, En studie med kvantitativa metoder av folkundervisningen i Bygdeå socken 1845-1873 (Umeå, 1972); Egil Johansson, The history of literacy in Sweden: in comparison with some other countries (Umeå, 1977). 
migration. ${ }^{61}$ Another American study from the early twentieth century found that breast-fed infants increased their survival chances threefold. ${ }^{62}$

It is thus apparent that the inclination of mothers to breast-feed has indeed varied over time and from place to place. Its potentially profound impact on infant mortality rates is also well-established. The velocity of such changes may be difficult to determine because of random short-term fluctuations and group differentials in small areas, but A. Brändström's research in Torneå suggests that much can happen in less than a decade. We have also seen that fashions and information connected with different nursing techniques did not stop at national borders - until 1814 Norway was part of the Danish Kingdom which also contained German states. The classic story about how prominent constitutional assembly member Peder Anker, squire on Bogstad estate outside Oslo, had his linen washed and starched in London, testifies to the importance of international style among the leading class in Norway. Or take the founder of the Figenschou dynasty in Troms, who was probably the cousin and Copenhagen neighbor of Niels Stensen, a frontal figure in seventeenth century European medicine. ${ }^{63}$ The trade and migration routes between the Norwegian coast communities in the south and the rest of Europe were also channels of information. ${ }^{64}$ The more than 24,000 people who had surnames of foreign origin according to the 1801 census, also suggest the free flow of cultural impulses from abroad. .5 $^{\circ}$

Even though the relationship between breast-feeding and a lower IMR has been so convincingly demonstrated for Norway's neighboring countries, we cannot automatically jump to the conclusion that widespread breast-feeding explains the land's low infant mortality. As in most countries, source material about nursing practices is scarce. The best material originated in the obstetrics hospitals of Christiania, Bergen and Trondheim, where unwed mothers came to have their babies and were followed-up with detailed studies that show that breast-feeding was the usual

61 Milton Myron Gordon, Assimilation in American life: the role of race, religion, and national origins (New York, 1964).

62 Michael R. Haines and Samuel H. Preston, Fatal years: child mortality in late nineteenth-century America (Princeton, N.J., 1991).

63 Personal communication from Hans Kermit, Niels Stensen's biographer.

64 Sølvi Sogner, Ung i Europa: norsk ungdom over Nordsjøen til Nederland i tidlig nytid (Oslo, 1994).

65 Sølvi Sogner og Gunnar Thorvaldsen, "Surnames as proxies for place or origin in the 1801 census for Norway". In Jørgen Carling (ed) Nordic Demography: Trends and differintials. Scandinavian Population Studies vol 13. Unipub forlag, Oslo 2002. 
practice. ${ }^{66}$ Since, according to other investigations, illegitimate children were more unlikely to be breast-fed than other children, this is good evidence in support of breast-feeding. However, it is not necessarily representative for other regions or other periods. Nor can we rely on oral testimony. Even the most retentive memories of old midwives or mothers today naturally remember the situation when the new infant care measures of the early twentieth century were common, not the practice of earlier periods.

A. Brändström's dissertation has identified Swedish parishes where the cause and effect pattern between breast-feeding and infant mortality can be clearly demonstrated, and other areas where this is not possible. But since nursing remains a key factor to look into when IMR differentials are to be explained, it is natural to look for a Norwegian case. The Setesdalen physician's district, a valley stretching towards the southern tip of Norway, is an obvious selection. This is a well-defined area with a clear decline in infant mortality that occurs so late that it ought to be subject to comments by the district doctor. Fortunately, he printed a report in the journal of the Norwegian Medical Association telling how he fought the conservative attitudes of the grandmothers during the 1880s. ${ }^{67}$ His vivid report blames the special culture in the valley. Even if his writing is colored by a lack of understanding for the way of life of ordinary people so common among civil servants, some of his observations seem relevant. His complaints about the very tight clothing of infants that hindered their breathing probably hints at a factor with an unknown effect on survival chances, but his observation that they were regularly fed foodstuffs such as potatoes and sour milk, in addition to breast milk, certainly is important. He states "they got other people's food." This mixing of artificial nourishment and breast-feeding can be used by the historian to explain nineteenth century infant mortality rates in between those found in areas with little breast-feeding (one third of all births) and levels found in places where mother's milk was widely used (one tenth of all births). Respiratory illnesses were frequent in all age groups, so he had a hard time convincing people that these maladies could kill children, since older children and grown-ups survived them. The doctor identified bronchitis and pneumonia as the biggest killers of infants. Secondly, there were frequent cases of diarrhea that took the lives of many infants, but that were erroneously classified as secondary symptoms, such as cramps. (The doctor may have been implicitly criticizing the clergyman's record keeping.) Relative to the illnesses mentioned above, the doctor was of the opinion that the ordinary children's diseases that appeared at regular

66 Margit Rosenberg, On the relation between living conditions and variables linked to reproduction in Norway 1860-1984 (Oslo, 1991).

67 J G H Stang, "Aarsagerne til den store barnedødelighet i Sætersdalens lægedistrikt," Tidsskrift for den norske Lageforening 18 (1898), 488-496. 
intervals were only minor causes of child mortality, even if such diseases were much more feared by the population. Older children must also have been malnourished if they, as he suggests, were only fed sour milk until five years of age. He also complained about lack of cleanliness and the poor quality of housing. By the turn of the century (1900) infant mortality had declined substantially in the valley, probably as a result of Doctor Stang's campaign for better child care, including breast-feeding. Can this explanation be generalized to apply to other regional developments in infant mortality?

The other area where high infant mortality was found in the 1850s, as well as half a century earlier, was along the coast of western Norway. This is illuminated in a local study, utilizing a data set that is extraordinarily complete and reliable. ${ }^{68}$ Peaking at even higher levels in the eighteenth century, the IMR fell from around 28 percent before 1785 to levels around eight percent during the last half of the nineteenth century. Although some of the high IMR levels in Etne in comparison with other parishes may be explained by the very complete data, we can still regard this study as representative of the high mortality area in the west. Some of the results, such as the IMR by month of the year, may build on numbers that are too small, but the finding that farmers' infants had higher IMR levels than cotters' and the dating of the initial decline of the IMR during the last two decades of the eighteenth century seem authoritative. Dyrvik relates the high IMR during the first weeks of life to artificial feeding, as in Brändström's study of Haparanda, especially when the women had to partake in the seasonal farm work. The most interesting hypothesis advanced by the author is that the IMR increased in years with harvests problems or bigger birth cohorts, because the women consciously sought to limit the size of their families by denying their children the protection of breast milk. A problem with this hypothesis is that most women presumably also knew that lactation prolonged the period between births, and such action would thus neutralize breast-feeding as a means of population control. ${ }^{69}$ Therefore, I would rather suggest that during hard times women were forced to leave their children in

68 Ståle Dyrvik, “Spedbarndøden i Etne prestegjeld 1716-1900,” in Festskrift til Historisk institutts 40-års jubileum 1997, eds. Edgar Hovland, Ståle Dyrvik, and Geir Atle Ersland. Skrifter/Historisk institutt. Universitetet i Bergen (Bergen, 1997), 131-150.

69 While longer inter-birth periods may neutralize the effect breast-feeding had on infant mortality, we should be open to the effect a change of feeding methods between siblings might have. If a mother breast-feeds one child and not the next, this will on average reduce family size by combining the postponing effect of lactation with the subsequently increased mortality risk of artificial food. This would make "sense" during a severe subsistence crisis. Reversely, changing from artificial food to breast milk between siblings would on average increase family size, and thus require economic opportunities only found in good times. 
order to perform extensive work or were more willing to let others take care of them with artificial foodstuffs during a period when breast-feeding was out of fashion.

The district physician on the coast north of Bergen was astonished to find no educated midwife there upon his appointment in 1855. Even if we compensate for the general derogatory attitude of civil servants towards the populace, it is difficult to imagine that the doctor invented his description of how the lay midwives treated women who suffered difficult deliveries. Doctor Krohn fought a tough political battle for nearly two decades before convincing the local assembly in one of the parishes to pay for an educated midwife. This report says little about infant mortality or breast-feeding, but claims that the lack of expertise and of traditional midwifery increased the chances of stillbirths or dying in labor. The number of stillbirths was higher in this district than nationally and is correlated with the number of educated midwives over time. It is interesting that the high infant mortality areas on the western coast saw significant improvement, just as this district doctor fought to introduce midwives and improve obstetrics and child care. He was especially critical of the conservative population in Manger parish that obstinately continued to use magical folk remedies despite his inspired lectures on reform. ${ }^{70}$ The report makes the important point that the doctors' fight to employ trained midwives was more beneficial than their own medical activities, especially since the midwives were key agents in the campaigns favoring breast milk.

As can be observed above, the region with high infant mortality north and east of Tromsø improved relatively little until the twentieth century. The municipalities with infant mortality reaching over one fifth of all births were found both furthest north and furthest east. While there is no direct proof that this was related to artificial feeding of infants, it is possible to establish a chain of circumstantial evidence. Finnmark and the northern parts of Troms province have been called "the meeting place of the three tribes." It must have been difficult for the Norwegian medical authorities to reach out to the Sami and Finnish ethnic groups that made up a majority of the population in Finnmark with information about child care, due to both cultural and linguistic barriers. It is part of the relative stability of the IMR level in the northernmost part of Norway that IMR levels there were reported as lower than in western Norway around 1800. While there is suspicion that this low level may have been caused by under-reporting of infant deaths, another explana-

70 Helge Sandvik, "Fødselsomsorgen i Ytre Nordhordland 1858-87. En sammenlikning med nasjonal statistikk," Tidsskrift for Den Norske Lageforening 113:30 (1993), 3715-7; Helge Sandvik, “'Dei Vise forvidle Væræ.' En distriktsleges kamp mot overtro og trolldom på 1800-tallet," Tidsskrift for Den Norke Lageforening 113: 29 (1993), 3572-4. 
tion would be in line with Swedish findings about the Sami population. ${ }^{71}$ While their "natural," as opposed to artificial, modes of child care were seen as an ideal in the eighteenth century, later on the practices of the majority population were favored by the medical authorities. Does this mirror a real shift in infant mortality levels connected with changed nursing practices?

The medical reports from Troms and Finnmark in the 1850s and 1860s say little about breast-feeding. Given the general propensity of civil servants to complain about the misdeeds of the common man, it seems reasonable to interpret this as a sign that many infants were breast-fed. This seems all the more likely in a region where cow's milk was scarce during the winter season, and reindeer milk cannot be fed to infants because it thickens. In his report for 1853, the garrison doctor in Vardø complained about the dirty breast of a nursing mother. He was aware of the healthy effects of breast milk, but recommended more cleanliness.

Inconsistent nursing practices may explain why infant mortality rates in Finnmark were lower than in areas where women did not breast-feed. The rates are in between the high levels found in Iceland and the low infant mortality districts in Denmark or Norway, which may have been caused by either a proportion of the women not nursing, the early use of additional foodstuffs or a nursing period that was too short. Given the heavy workload of women along the coast, it may not always have been easy to find the opportunity for nursing infants. The extensive nature of the peasant fishing economy and the absence of men during the fisheries often left women of fertile age in charge of most of the production on land. ${ }^{72}$ Although women who participated in the seasonal fisheries were only occasionally found, they were widely employed in fish processing ashore or were out on the fjord to catch the day's dinner. Letting younger or older family members care for the children while the mother did extensive farm work or other tasks must have been usual, with substitute foodstuffs for the infants being the logical consequence. Giving food containing starches or non-pasteurized cow's milk to infants easily leads to diarrhea, which together with respiratory diseases, was the most common cause of death among infants. In contrast, the beneficial effect from mother's milk on the immune system, especially from the initial colostrum, is well-known.

A. Brändström's findings of high infant mortality due to lack of nursing among the Finns in Haparanda, Sweden make it natural to focus on the situation of this ethnic group in Finnmark. The Finns were clever farmers with more stable access to

71 Anders Brändström, "Från förebild till motbild. Spädbarnsvård och spädbarnsdödlighet i Jokkmokk," in Älvdal i norr, ed. Sune Åkerman (Luleå, 1988), 307-352.

72 Governor's report for Finnmark 1866-70, 23 and 28 
cows' milk." "In this respect the Finnish population set a good example; it is used to a rich consumption of milk from its homeland." The Medical Officer of Health in 1864 reported that the Finnish women in Vadsø would not employ the trained Norwegian midwife, most likely because of disagreement about birth procedures and child care. Brändström describes similar conflicts in Haparanda. We also know that areas of out-migration from Finland to Norway were characterized by extensive female farm work, lack of nursing and relatively high levels of infant mortality. ${ }^{74}$ Lithell emphasizes the female workload as the main cause, while Brändström stresses a more cultural explanation. In my view these hypotheses may be combined in the argument that, although the economic situation improved during the first part of the nineteenth century, a reformed infant-feeding culture did not develop until the second half. Causal links between the relatively high levels of infant mortality and fertility may have worked in both directions and should be investigated using individual level data. While it has been proved that the high infant mortality among the Finns resulting from artificial feeding did not stop at the border with Sweden, there is less direct evidence in the case of their migration to northern Norway. In addition to the circumstantial evidence cited above, there is an interesting parallel in the exceptionally high mortality among infants born to French-Canadian mothers, while children of Scandinavian mothers did better than average in the US around 1900. "Apart from breast-feeding, however, there seems to be little that can be said quantitatively about the different modes of child-rearing as they might influence ethnic variation in child mortality." 75

In a letter from 1917 Margit Qvigstad described infant care among the Sami, giving a favorable picture where nursing was standard procedure. ${ }^{76}$ Even if her impression may have been based more on the nomads than on the coastal Sami, this is further evidence that nursing was usual. Since nursing became more common in many places during the last part of the nineteenth century, however, we cannot base a notion of consistent nursing on this late source. Fortunately, a newly discovered ethnographic manuscript from 1896 gives a detailed account of Sami living conditions based on a teacher's study of two localities in Troms and Finnmark. ${ }^{77}$ The

73 Ivar Bjørklund, Fjordfolket i Kvenangen (Tromsø, 1985); Medical report for Finnmark 1875.

74 Ulla-Britt Lithell, Kvinnoarbete och barntillsyn i 1700- och 1800-talets Österbotten (Uppsala, 1988).

75 Michael R. Haines and Samuel H. Preston, Fatal years: child mortality in late nineteenth-century America (Princeton, N.J., 1991), 42.

76 Appendix to letter for Katti Anker Møller, 1/9 1917, in the Manuscript Collection of the Norwegian National Library, Ms 402416 I D. I am grateful to Bjørg Evjen for the reference.

77 Ole Thomassen, Lappenes forhold (Gáivuona, 1999). 
infants were said to be nursed until they were nearly one year-old. However, a rag with cream was introduced until the mother could nurse, and this was also used if she had insufficient breast milk. A. Løkke reports the use of similar rags in eastern Jutland in Denmark, an area that had high infant mortality. ${ }^{78}$ Popular belief that the first, bluish milk was not nourishing was widespread, and this prevented many infants from receiving the valuable addition of colostrum to their immune system. While the extent and timing of giving additional foodstuffs to babies has still not been explored, there is every reason to pursue the nursing issue with individual level data. The Bourgeois-Pichat test, which is widely acclaimed as a good indicator of breast-feeding, has been applied to data from a number of parishes in the northernmost provinces during the nineteenth century. The timing of infant deaths graphed logarithmically using this method indicates that nursing was less consistent in Finnmark than in Troms. ${ }^{79}$

Given that infant mortality remained high in Finnmark, why is there so little evidence of campaigning for better child care on the part of the authorities, in contrast to northern Sweden and Finland? The inaccessibility of some areas can form only part of the explanation. In addition, the slow decline in the infant mortality rate from the turn of the century (1900) may have convinced the authorities that their efforts to culturally integrate the Sami and Finns had the desired effect. The ethnic Finns in Sweden had dominated their territories for centuries, while much of the migration from Finland to Norway was a nineteenth century phenomenon, even though there were smaller groups of Finns who had been resident in Norway for generations. It is likely that second-generation Finnish immigrants breast-fed more extensively. The arguments in this case would find their parallel in the explanations as to why most groups of second-generation immigrants to the US had mortality patterns more like the native-born population. ${ }^{80}$

Still, both infant and child mortality in the northernmost province of Norway remained high during the early decades of the twentieth century. Recent research has demonstrated fairly convincingly that the key factor in bringing down infant mortality figures during this period was the dissemination of information to medical personnel and, by means of them, to the parents. ${ }^{81}$ When this was not as suc-

78 Anne Løkke, Døden i barndommen (København, 1998), 175.

79 Gunnar Thorvaldsen, "Infant mortality in Northern Finland, Sweden and Norway," (Paper for the Social Science History Conference, Pittsburgh 2000), 17.

80 Samul H. Preston, et al., "Child mortality differences by ethnicity and race in the United States 1900-1910," in After Ellis Island. Newcomers and Natives in the 1910 Census, ed. Susan Cott Watkins (New York, 1994), 35-82.

81 Michael R. Haines and Samuel H. Preston, Fatal years: child mortality in late nineteenth-century America (Princeton, N.J., 1991). 
cessful in Finnmark as in the rest of Norway, I would like to raise a warning flag against interpreting the long-lasting high mortality there as the downside of the struggle of the Sami and the Finns to keep their cultural identity intact. From the late nineteenth century the official policy of the Norwegian state was to "norwegianize" the ethnic minorities, for instance, by sending children to boarding schools and allowing them to speak only Norwegian. Pedagogical research shows, however, that successful education must take the pupils' mother tongue as the starting point. The effort to get rid of the Sami and Finnish cultures fortunately failed, but the wasted resources hindered other vital educational projects for all ethnic groups. The failure to teach the population of Finnmark about better child care at the same pace as in the rest of the country should thus be seen as one of the worst consequences of Norway's minority policy at the time.

The studies made of infant mortality in Asker and Bærum are particularly interesting, both because they build on a rich and linked data set from the censuses and church registers, and because the parish had the same IMR level as was the average for Norway around $1800 .^{82}$ The parish lies directly southwest of Oslo, bordering on the Oslo Fjord, and had iron foundries in addition to agriculture. The infant mortality rate started to decline a couple of decades before 1800 , but 1809 was still a year of crisis with many infant deaths, as were 1748 and 1761. It seems that infants were affected by these crises, but not to the extent of the population in general. The 1809 crisis affected infants and old people in particular and is therefore interpreted by the author as caused by an epidemic. Since the IMR is a valuable measure of a population's general welfare, in an article referred to above E. Fure has interpreted the decrease in infant mortality as a sign of more abundant resources, giving children better chances of survival in the synergistic struggle with contagious diseases. She admits, however, that the lack of significant correlations between the IMR level and social class both in her studies and elsewhere weakens this line of reasoning. ${ }^{83}$ In her conclusion Fure discusses the connection found in Trondheim between reduced infant mortality and medical information, particularly that favoring breast-feeding, but she finds this difficult to accept for Asker and Bærum since medical services, such as midwives and doctors, were practically absent in the

82 Eli Fure, "Spedbarndødelighet og sosiale forskjeller i Asker og Bærum 1814-1878. En metode for studier på individnivå," Heimen 37:4 (2000), 293-304; Eli Fure, "Nedgangen i dødeligheten i Asker og Bærum 1733-1878," Heimen 36:3 (1999), 177-186.

83 The rural character of the localities may explain this. It is interesting that infant mortality differences are bigger among occupational categories in the urban areas of the US and Britain, due both to the variations in living conditions and the reverse causal effect of women who lost children returning to work. Michael R. Haines and Samuel H. Preston, Fatal years: child mortality in late nineteenth-century America (Princeton, N. J., 1991). 
parish. I would like to point out that information relayed from woman to woman could be more efficient than official propaganda - especially if it came from one's equals or people with higher status. ${ }^{84}$ The parish of Bærum borders on Lake Bogstad, where the squire lived who sent his linen to London to be cleaned. The 1801 census lists some twenty servants on his estate in addition to several associated households, suggesting widespread contacts with the surrounding community. I thus agree with Dyrvik's view that the main change was one of attitudes in the collective of women. ${ }^{85}$ Clergymen and doctors were not their only channels of communication with the outside world. And since the population in these parishes was ethnically homogeneous, the information channels were not blocked by cultural or linguistic barriers, and thus reforms might leave few traces in the source material. As indicated by the Brändström-Lithell debate, this does not rule out the possibility that more affluence and less work, allowing women to spend more time with their children, could help make a shift in feeding practices feasible. Recently, an authoritative study of the grain supply to Norway has concluded that the country's population had already experienced an increased standard of living in the eighteenth century. ${ }^{86}$ This is in line with the reasoning of the next local study.

Fortunately, a traditionally low infant mortality parish has been studied using the very complete and reliable nominative records. Rendalen is a rather isolated inland municipality on the Swedish border, midway between Lillehammer and Trondheim. ${ }^{87}$ In this area the IMR fluctuated between ten and twenty percent in the eighteenth century, declining quite steadily from the 1770s until a level of five or six percent was reached a century later. The parish may thus be taken as representative for the inland areas of southeastern Norway. During the last half of the eighteenth century the cotters' children had a somewhat higher IMR than did the farmers' children, but there was little difference between the rates for legitimate and illegitimate births. Breast-feeding is assumed to have been more or less general, and factors such as cleanliness and a sparsely settled area also promoted low infant mortality. The author's hypothesis is that the simultaneous decline in women's mortality indicates better times for housewives due to increased family income from the region's developing forest industry towards the end of the eighteenth century. Compulsory smallpox vaccination from 1810 onward and a health service with district physicians

84 Leonard and Philip Selznick Broom, Sociology. A text with adapted readings, 4 ed. (New York, 1968), 236ff.

85 Ståle Dyrvik, "Spedbarndøden i Etne prestegjeld 1716-1900," in Festskrift til Historisk institutts 40-års jubileum 1997, eds. Edgar Hovland, Ståle Dyrvik and Geir Atle Ersland, Skrifter / Historisk institutt. Universitetet i Bergen (Bergen, 1997), 131-150.

86 John Herstad, I helstatens grep: kornmonopolet 1735-88 (Oslo, 2000), 200.

87 Sølvi Sogner, Folkevekst og flytting (Oslo, 1979). 
and midwives from the middle of the nineteenth century were other factors contributing to even lower infant mortality rates.

Regretably, we have no similar local study from the low mortality area in central Norway, since the one from Trondheim does not use linked nominative sources, and, as an urban study, it cannot be seen as representative for the region. ${ }^{88}$ Even so, it is interesting how the author stresses medical knowledge and the promotion of breast milk as her main explanation for the lowered IMR levels. Further studies from the provinces of Trøndelag and Nordland are necessary in order to explain why Norway's lowest infant mortality in the first part of the nineteenth century, contrary to expectation, can be found along the coast. A likely set of explanatory factors is, however, that the population there lived more scattered than along the coast of western Norway, a region where it was easier to combine fishing with agriculture than north of the polar circle. In addition, as in Rendalen, the greater distance from the leading European countries may have lessened the impact of fashion cycles in breast-feeding. Thus far studies of the medical reports have given just a few clues, in addition to the usual reports of illnesses, occasional epidemics and harvest problems. One medical report states that in the province of Nordland it was unusual to have cows' milk during the winter, breast milk being the most likely alternative for infants. ${ }^{89}$ Another indication of widespread breast-feeding is found in the report for Brønnøy parish in 1862. The doctor listed the age of the many children who died from a diphtheria epidemic that year, but very few were infants, indicating a strengthening of their immune systems with mother's milk.

Even though we have no decisive proof in the form of nursing statistics, there are a number of indications that more widespread breast-feeding connected with fashions in nursing and a more affluent population can explain at least parts of the decline in infant mortality from the late eighteenth century. We must, however, also confront the competing hypothesis about a milder epidemic climate. It is naturally possible that epidemic diseases came less frequently to Norway, or that the bacteria and viruses in question had become less virulent and dangerous. The difficulty inherent in this reasoning is that it is so difficult to test, and this to a greater extent than is the case with the nursing hypothesis. Even present-day illnesses and their relative strength are not easy to measure, and for historical illnesses there are no specimens. ${ }^{90}$ That higher death rates in urban or densely populated areas are due

88 Margunn Skjei Knudtsen, Fra frelse til helse: spedbarnsdodelighet og omsorgssyn i Norge ca 1700-1830 med serlig vekt på forholdene $i$ Vår Frue sokn, Trondheim (Trondheim, 1997).

89 Medical report for Alstahaug 1858. Norwegian National Archives Pakke 180, RA 3A0893/1.

90 The recent alleged excavation of virus from the Spanish flu has thus far brought no solution as to why the epidemic climate in 1918 was especially dangerous for young men. 
to contagious illness is a commonplace, but a reduction in their illness frequency or death rate could still be due to improved immunity among the population.

If the high mortality areas are considered, people along the coastline would naturally be more exposed to disease, and there may have been more traffic along the western coast of Norway with its seasonal fisheries. But then the low mortality area in Nordland, where most of the population lived right on the coast and participated regularly in the Lofoten fisheries, would become a mystery. Further north, the high mortality rates in Finnmark might be explained by contagion coming in from the east, but, on the other hand, the long distances between settlements should have prevented the spread of diseases. The example of Finnmark also shows how difficult it can be to measure population density empirically. While the population per unit area was very small, most people lived in village-like places rather than on the single farms more usual in southern Norway. The scarcity of building material made people cram together into rather small houses, in contrast to the spacious homes in Rendalen. However, it is not easy to understand why the epidemic climate should be much tougher in Setesdalen than along the Swedish border. Recent research substantiates the likelihood of extended households being usual in Rendalen, ${ }^{91}$ so many people probably shared the same house during the long winter there, as well as in Finnmark. But with the relative lack of building material in the north, and the many fishermen who lived as boarders during peak seasons, the number of people per room or unit area was probably significantly larger there. ${ }^{92}$

A multivariate study of the statistical correlation between mortality, population density and other factors along the lines described above for Germany awaits the on-going work of encoding the 1900 census. ${ }^{93}$ Thus far, exploratory calculations for the period 1886-1890 show the municipal level correlation (Pearson's r) between IMR and proportion of illegitimate births to be close to zero. Johannesen found the illegitimate children of Christiania to be over-represented among diseased infants in the summer, while Sogner found no such effect for rural Rendalen. Thus, the reason may be that there were many more rural than urban municipalities in Norway. The correlation between the IMR and a fertility measure (children born

91 Hans Henrik Bull, "Hushold og genrasjonsskifter i Rendalen 1762-1900. Ættesamfunnets siste skanse?” (Universitetet i Oslo, 2000).

92 Gunnar Thorvaldsen, "Northern, Eastern or Urban Penalty? Aspects of Late 19th Mortality in the North of Norway," in Papers from the Nordic Demographic Symposium in Umea, August 1999 [In print], eds. Peter Sköld and Lars-Göran Tedebrand (Umeå: Umeå University, 2001).

93 For the rural areas the 1900 census only gives the number of inhabited buildings per dwelling unit, while the urban questionnaires asked for detailed information such as the number of rooms on each floor and the number of persons living there. 
per married woman aged, 15-45) was also close to zero, while the correlation between the IMR and the proportion of dead children aged 1-2 was significant and as large as .42. I have interpreted this as an indicator that, towards the end of the nineteenth century, breast-feeding was quite universally distributed among most (rural) municipalities, no longer explaining child spacing differentials at this level. The remaining correlation between mortality rates in the first and second year of life might be explained by remaining geographical differences in hygienic conditions and child care practices other than nursing. ${ }^{94}$

From the last decades of the nineteenth century, an increasing number of public health measures were enforced that also promoted the care of mothers and their infants. These measures ranged from clean water supply to health stations for mothers with newborn babies. Such measures have been described in detail for Denmark, but the development in Norway was parallel. ${ }^{95}$ There can be no doubt that the information about better child care, including propaganda for breast-feeding, was the principal cause behind bringing the infant mortality rate below ten percent in all towns and all provinces but one before World War I. The exception was Finnmark, where communications and, to some degree, language problems made information work difficult even after World War II. ${ }^{96}$ The importance of housing was highlighted when the infant mortality rate increased in Tromsø during the last year of the Second World War, as the population north of the city was evacuated southwards by the retreating Germans. ${ }^{97}$

Very little evidence has been found that the general nutritional status of the population affected infant mortality historically, with the exception of some years of crisis. If parents did not know how to promote the health of their infants, the wealth of higher social class had little impact. ${ }^{98}$ If wealthy parents tended to live in densely populated places, for instance along the coast where contagion spread more easily, it might more than offset their material advantage. A change in the epidemic climate cannot be entirely ruled out as having reduced the level of infant deaths in

94 The correlation between IMR and proportion of stillbirths is weaker, only .25, but significant, and could also indicate differences in the conditions surrounding new mothers, for instance, access to trained midwives. However, the correlation between stillbirths and the municipality identification number is equally strong. Does this indicate that the concept of stillbirth is not interpreted universally across Norway?

95 Axel Johannessen, Dødeligheden i Norge af børn under 1 aar (Christiania, 1902).

96 Knut Rein, "Spebarndødeligheten i Kautokeino 1946-1955," Tidsskrift for Den norske lageforening, 76 (1956): 815-816.

97 Berit Nøkleby and Guri Hjeltnes, Barn under krigen (Oslo, 2000).

98 Michael R. Haines and Samuel H. Preston, Fatal years: child mortality in late nineteenth-century America (Princeton, N. J., 1991). 
previous centuries, but such a claim is in principle nearly impossible to substantiate. If general causes are sought that are valid over time throughout the country and that may also be applied outside Norway, breast-feeding and other elements of proper child care are the most likely candidates. The indications that breast-feeding became less fashionable in Europe from the seventeenth century are overwhelming, and there is also evidence that it became more usual for mothers to leave their infants in the care of older children or wet nurses. There is virtually no information about infant mortality in Norway before the eighteenth century, so the role of changing breast-feeding fashion in fluctuations in infant mortality cannot be established. But according to the center-periphery model of information flow, it is likely that the influence of fashions from the Continent and Britain had a greater impact on the west coast and in southern Setesdalen than further east and north. The low infant mortality in the middle part of the country must have been due to a combination of factors: easier living conditions than further north and a greater distance from European centers. As information about the beneficial effects of mother's milk spread from the last part of the eighteenth century and more affluence gave women better chances to practice breast-feeding, infant mortality rates dropped gradually. With the infant care measures introduced by the authorities from the late 1800 s, this development accelerated until the early twentieth century.

It is my hope that this overview can stimulate further research into the causes of the mortality decline from qualitative and quantitative evidence on the local level.The low infant mortality zone in the province of Nordland and the high IMR areas in Finnmark and in Setesdalen are obvious candidates for such studies.

Gunnar Thorvaldsen is Professor at the Norwegian Historical Data Centre, University of Tromsø, 9037 Tromsø, Norway. 